\title{
Variability of air ion concentrations in urban Paris
}

\author{
V. N. Dos Santos ${ }^{1}$, E. Herrmann ${ }^{1,2}$, H. E. Manninen ${ }^{1}$, T. Hussein ${ }^{1}$, J. Hakala ${ }^{1}$, T. Nieminen ${ }^{1,4}$, P. P. Aalto ${ }^{1}$, M. Merkel ${ }^{3}$, \\ A. Wiedensohler ${ }^{3}$, M. Kulmala ${ }^{1}$, T. Petäjä ${ }^{1}$, and K. Hämeri ${ }^{1}$ \\ ${ }^{1}$ University of Helsinki, Department of Physics, P.O. Box 48, 00560 Helsinki, Finland \\ ${ }^{2}$ Laboratory of Atmospheric Chemistry, Paul Scherrer Institute, Villigen, Switzerland \\ ${ }^{3}$ Leibniz Institute for Tropospheric Research, Permoserstraße 1504318 Leipzig, Germany \\ ${ }^{4}$ Helsinki Institute of Physics, P.O. Box 64, 00014 University of Helsinki, Helsinki, Finland
}

Correspondence to: V. N. dos Santos (vanessa.dossantos-juusela@helsinki.fi)

Received: 18 February 2015 - Published in Atmos. Chem. Phys. Discuss.: 13 April 2015

Revised: 19 October 2015 - Accepted: 20 November 2015 - Published: 14 December 2015

\begin{abstract}
Air ion concentrations influence new particle formation and consequently the global aerosol as potential cloud condensation nuclei. We aimed to evaluate air ion concentrations and characteristics of new particle formation events (NPF) in the megacity of Paris, France, within the MEGAPOLI (Megacities: Emissions, urban, regional and Global Atmospheric Pollution and climate effects, and Integrated tools for assessment and mitigation) project. We measured air ion number size distributions $(0.8-42 \mathrm{~nm})$ with an air ion spectrometer and fine particle number concentrations $(>6 \mathrm{~nm})$ with a twin differential mobility particle sizer in an urban site of Paris between 26 June 2009 and 4 October 2010. Air ions were size classified as small (0.8$2 \mathrm{~nm})$, intermediate $(2-7 \mathrm{~nm})$, and large $(7-20 \mathrm{~nm})$. The median concentrations of small and large ions were 670 and $680 \mathrm{~cm}^{-3}$, respectively, (sum of positive and negative polarities), whereas the median concentration of intermediate ions was only $20 \mathrm{~cm}^{-3}$, as these ions were mostly present during new particle formation bursts, i.e. when gas-to-particle conversion produced fresh aerosol particles from gas phase precursors. During peaks in traffic-related particle number, the concentrations of small and intermediate ions decreased, whereas the concentrations of large ions increased. Seasonal variations affected the ion population differently, with respect to their size and polarity. NPF was observed in $13 \%$ of the days, being most frequent in spring and late summer (April, May, July, and August). The results also suggest that NPF was favoured on the weekends in comparison to workdays, likely due to the lower levels of condensation sinks in the mornings of weekends (CS weekdays 09:00: $18 \times 10^{-3} \mathrm{~s}^{-1}$; CS weekend 09:00: $\left.8 \times 10^{-3} \mathrm{~s}^{-1}\right)$. The me-
\end{abstract}

dian growth rates (GR) of ions during the NPF events varied between 3 and $7 \mathrm{~nm} \mathrm{~h}^{-1}$, increasing with the ion size and being higher on workdays than on weekends for intermediate and large ions. The median GR of small ions on the other hand were rather similar on workdays and weekends. In general, NPF bursts changed the diurnal cycle of particle number as well as intermediate and large ions by causing an extra peak between 09:00 and 14:00. On average, during the NPF bursts the concentrations of intermediate ions were 8.5-10 times higher than on NPF non-event days, depending on the polarity, and the concentrations of large ions and particles were 1.5-1.8 and 1.2 times higher, respectively. Because the median concentrations of intermediate ions were considerably higher on NPF event days in comparison to NPF nonevent days, the results indicate that intermediate ion concentrations could be used as an indication for NPF in Paris. The results suggest that NPF was a source of ions and aerosol particles in Paris and therefore contributed to both air quality degradation and climatic effects, especially in the spring and summer.

\section{Introduction}

In the last decade, with the threat of climate change, a growing number of researchers have focused on understanding the association between aerosol particles and the climate. Aerosol particles are either directly emitted into the atmosphere (primary particles) or formed in the atmosphere (secondary particles). Freshly formed secondary aerosol particles may grow within a day or two up to sizes where they can act 
as cloud condensation nuclei $(\mathrm{CCN})$ and affect the radiation budget of the Earth (Makkonen et al., 2012; Kerminen et al., 2012; Wiedensohler et al., 2009). Merikanto et al. (2009) estimated that $45 \%$ of the global tropospheric $\mathrm{CCN}$ at $0.2 \%$ super saturation are originated from secondary particle formation. In addition to the climatic effects, the formation and growth of secondary aerosol particles contributes to the deterioration of the air quality as aerosol particles are associated to adverse health effects (Oberdörster et al., 2005). Despite its importance, the mechanisms underlying secondary new particle formation are not yet fully understood (see Kulmala et al., 2014).

In the atmosphere, new particle formation (NPF) occurs in different steps including formation of low volatile vapours, clustering of vapour molecules and subsequent growth (see Kulmala et al., 2014). The presence of air ions can facilitate the formation and growth of new particles by aiding the stabilization of the molecular clusters during the initial stages of nucleation (so called ion-induced nucleation) (e.g. Yu and Turco, 2000). The magnitude of the contribution of ions to atmospheric NPF however is still under investigation. On one hand, several studies reported a rather low contribution of ion-induced nucleation to the total NPF events, 10-30\% (Hirsikko et al., 2011, and references therein), with even lower values observed in urban areas, $0.2-1.3 \%$ (Gagné et al., 2012; Iida et al., 2006; Herrmann et al., 2014). On the other hand, some models and chamber studies suggest that ion-mediated nucleation (which considers ion-ion recombination) may be a significant path for NPF (Yu and Turco, 2011; Yu, 2010; Svensmark et al., 2007; Nagato and Nakauchi, 2014). Chamber studies in the CLOUD project have shown that in low temperatures and at low precursor species concentrations, ion-induced nucleation can have a significant contribution to total nucleation rates (Kirkby et al., 2011; Riccobono et al., 2014). Based on earlier urban studies by Gagné et al. (2012), Iida et al. (2006) and Herrmann et al. (2014), we assume that ions and charged particles detected in Paris are the naturally charged fraction of total aerosol particles.

In this study, the air ions were mobility-classified as small or cluster ions $\left(3.2-0.5 \mathrm{~cm}^{2} \mathrm{~V}^{-1} \mathrm{~s}^{-1}\right)$, intermediate $\left(0.5-0.034 \mathrm{~cm}^{2} \mathrm{~V}^{-1} \mathrm{~s}^{-1}\right)$, and large ions $(0.034$ $0.0042 \mathrm{~cm}^{2} \mathrm{~V}^{-1} \mathrm{~s}^{-1}$ ), which correspond to mobility diameters of $0.8-2,2-7$ and $7-20 \mathrm{~nm}$, respectively. Small ions are always present in the air and are responsible for the atmospheric electrical conductivity (e.g. Harrison and Carslaw, 2003; Hirsikko et al., 2011). They are mainly formed from ionizing radiation of decaying radon, gamma radiation and galactic cosmic radiation. Thunderstorms, water splashing, and rain and snow storms also contribute to the formation of air ions in the atmosphere (Virkkula et al., 2007; D'Alessandro, 2009; Tammet et al., 2009; Kolarž et al., 2012). Increased small ion concentrations have been observed in the vicinity of power lines (Jayaratne et al., 2008). Small ion emissions in fuel burning processes in engines or via nucleation from exhaust gas have been studied theoretically and experimentally (e.g. Yu and Turco, 1997; Haverkamp et al., 2004; Gopalakrishnan et al., 2005; Lähde et al., 2009; Jayatane et al., 2010; Ling et al., 2013). The most important sinks for ions are ion-ion recombination to form neutral particles, and attachment to pre-existing aerosol particles (Hoppel, 1985; Hoppel and Frick, 1986).

Urban areas are important sources for global aerosol and $\mathrm{CCN}$ load because they emit both primary particles and precursors for secondary particle formation. Nevertheless, the number of studies focusing on the behaviour of air ions and particularly its association to NPF in urban areas around the world is still somewhat limited (e.g. Tiitta et al., 2007; Hirsikko et al., 2007b; Retalis et al., 2009; Tammet et al., 2014; Gagné et al., 2012; Herrmann et al., 2014; Backman et al., 2012; Crilley et al., 2014; Jayaratne et al., 2010, 2014; Ling et al., 2013; Ling et al., 2010; Siingh et al., 2013; Lee et al., 2012; Iida et al., 2006, 2008; Pikridas et al., 2015), and actually only some of them measured ion size distributions. The main aim of this study was to determine the frequency and seasonal variations of NPF events in a megacity based on ion number size distribution measurements. Our research was developed within the framework of the project "Megacities: Emissions, urban, regional and Global Atmospheric Pollution and climate effects, and Integrated tools for assessment and mitigation (MEGAPOLI)", which aimed to improve the understanding of the impacts of megacities on the climate. In this context, Paris, one of the largest cities in Europe, was chosen as case study. Although some publications on aerosol particles in Paris already exist (e.g. Crippa et al., 2013; Freutel et al., 2013; Freney et al., 2014; Sciare et al., 2010; Pikridas et al., 2015), only Pikridas et al. (2015) considered air ion number size distributions $(>0.8 \mathrm{~nm})$, which allows the evaluation of ion number concentrations in early stages of NPF. Pikridas et al. (2015) provided valuable information on the spatial variation of NPF events and particle number concentrations as well as on factors affecting NPF in Paris and surrounding areas. However, their study was based on rather short campaigns (about 2 months of data) and air ion number size distributions were used only to classify NPF events and to determine their duration and frequency. Our study complements Pikridas et al. (2015) by providing detailed information on the behaviour of air ion concentrations of both polarities in three different size ranges, and particle number concentrations in Paris for over 1 year.

\section{Materials and methods}

We measured air ion size distributions (0.8-42 nm) and aerosol particle number $(6-740 \mathrm{~nm})$ at an urban background site in Paris from 26 June 2009 to 4 October 2010, using an air ion spectrometer (AIS), and a combination of a twin differential mobility particle sizer (TDMPS) and condensation particle counter (CPC). In addition to seasonal variations and 
frequency of NPF events, we also analyzed seasonal variations and diurnal cycles of air ions and aerosol particles on workdays and weekends, and on NPF event and NPF nonevent days. Furthermore, we estimated the average condensation sinks, and the growth rates of ions on workdays and weekends, and provided a statistical summary of air ions and aerosol particle number concentrations in Paris.

\subsection{Description of the site}

Paris is a megacity with 12.2 million inhabitants in its urban area (2.2 million in the centre alone) (INSEE, 2010). Our measurements of air ion size distributions and particle total number concentrations were located at the Laboratoire d' Hygiène de la Ville de Paris building (LHVP) on 13th Arrondissement (latitude $48.83^{\circ}$; longitude $2.36^{\circ}$ ) in Paris (Fig. 1), from July 2009 to October 2010. Particle number size distributions were measured from a container on the ground of the LHVP building, whereas air ion size distributions were measured on top of the building (about $15 \mathrm{~m}$ high). LHVP is located about $400 \mathrm{~m}$ away from busy intersections and is considered an urban background site (Sciare et al., 2010; Favez et al., 2007). The site was surrounded by a small street, a park and restaurants (Freutel et al., 2013). According to Crippa et al. (2013), important anthropogenic sources of particles in the site are traffic, cooking (from restaurants around noon and evenings), and biomass burning in general, whereas an important natural source is secondary particle formation.

\subsection{Description of the instruments}

\subsubsection{Air ion number size distributions}

We used an Air Ion Spectrometer (AIS, Airel Ltd.) (Mirme et al., 2007) to measure the size distributions of naturally charged particles and ions of both polarities simultaneously during 26 June 2009-4 October 2010 in Paris, France. The AIS comprises of two identical differential mobility analysers (DMA), one for each polarity. Particle size is determined based on the electrical mobility of the particle in the electric field, and particle number concentration is calculated based on the intensity of the currents measured by the electrometers at an outer cylinder of the DMA. The AIS measures electrical mobilities varying from 3.2 to $0.0013 \mathrm{~cm}^{2} \mathrm{~V}^{-1} \mathrm{~s}^{-1}$, which is equivalent to mobility diameters of $0.8-42 \mathrm{~nm}$ (Mäkelä et al., 2006).

The main sampling line of the AIS was $0.6 \mathrm{~m}$ long (inner diameter: $35 \mathrm{~mm}$ ) with a total inlet flow rate of $60 \mathrm{~L} \mathrm{~min}^{-1}$ which was equally divided between both DMAs. A metallic grid was used in front of the inlet to prevent for instance large dust particles to enter the system. The sheath air flow of the DMAs was cleaned using corona chargers and electrical filters, and reused in a closed loop at $60 \mathrm{~L} \mathrm{~min}^{-1}$ (Gagné et al., 2011). The instrumental setup and calibration are described in more details by Mirme et al. (2007) and Asmi et al. (2009), respectively. The accuracy of the particle number concentration of the AIS was estimated to be $10 \%$, which was mainly due to flow rate uncertainties (Mirme et al., 2007). During the campaign the accumulating air pollution inside the instrument causes decreasing flow rates between the maintenance periods. This may further increase the uncertainty of measured particle size and number especially at the larger end of the measured spectra.

\subsubsection{Number size distributions and total concentrations of fine aerosol particles}

We used a twin differential mobility particle sizer (TDMPS) to measure the particle number size distribution (diameter 3-740 nm) during July 2009. The instrument comprised of a neutralizer, two Hauke DMAs (lengths: 110 and $280 \mathrm{~mm}$; both with inner and outer diameters of 50 and $67 \mathrm{~mm}$, respectively) and two condensation particle counters (CPC), models TSI $3025 \mathrm{~A}\left(d_{50}: 3 \mathrm{~nm}\right.$, accuracy $\pm 10 \%$ at $\left.10^{5} \mathrm{~cm}^{-3}\right)$ and TSI $3010\left(d_{50}: 10 \mathrm{~nm}\right.$, accuracy $\pm 10 \%$ at $\left.10^{4} \mathrm{~cm}^{-3}\right)$. The first DMA classified particles from 3 to $72 \mathrm{~nm}$, while the second DMA classified particles from 25 to $740 \mathrm{~nm}$. The sampling and sheath flow rates were 2 and $20 \mathrm{~L} \mathrm{~min}^{-1}$, respectively, for the first DMA, and 0.5 and $5 \mathrm{~L} \mathrm{~min}^{-1}$ for the second DMA. The sampled air was dried using an automated diffusion dryer (Tuch et al., 2009). According to Wiedensohler et al. (2012) the drier is estimated to cause about $28 \%$ and $8 \%$ of losses for particles of 3 and $10 \mathrm{~nm}$, respectively, for the given flow rate through the drier. The TDMPS data were averaged per hour.

We also measured the total number concentration of fine aerosol particles by using a condensation particle counter (CPC, TSI 3772, dp50: $6 \mathrm{~nm}$, accuracy $\pm 10 \%$ at $10^{4} \mathrm{~cm}^{-3}$ and $\pm 20 \%$ at $5 \times 10^{4} \mathrm{~cm}^{-3}$ ) during 11 August 2009-4 October 2010 . In order to reduce the cut-off diameter from typical $10 \mathrm{~nm}$ to $6 \mathrm{~nm}$, the condenser of the CPC was operated at $10^{\circ} \mathrm{C}$ instead of the common operational temperature of $22{ }^{\circ} \mathrm{C}$. The sampled air was dried using a Nafion dryer.

\subsection{Data treatment and definitions}

Air ion data containing negative concentrations (positive ions: $0.64 \%$ of all data; negative ions: $1.18 \%$ ), concentrations measured during unstable flow rates (optimum range: $1000 \mathrm{~cm}^{3} \mathrm{~s}^{-1} \pm 8 \%$ ) and very noisy data were considered invalid. A three-point median filter was applied to the ion concentrations to reduce noise as suggested by Kulmala et al. (2012). The air ions were mobilityclassified as small or cluster ions $\left(3.2-0.5 \mathrm{~cm}^{2} \mathrm{~V}^{-1} \mathrm{~s}^{-1}\right)$, intermediate $\left(0.5-0.034 \mathrm{~cm}^{2} \mathrm{~V}^{-1} \mathrm{~s}^{-1}\right)$, and large ions $(0.034$ $\left.0.0042 \mathrm{~cm}^{2} \mathrm{~V}^{-1} \mathrm{~s}^{-1}\right)$, which correspond to mobility diameters of $0.8-2,2-7$ and $7-20 \mathrm{~nm}$, respectively. In these size ranges charged particles are assumed to be single charged. In this study, we apply the mobility diameter, i.e. Millikan 

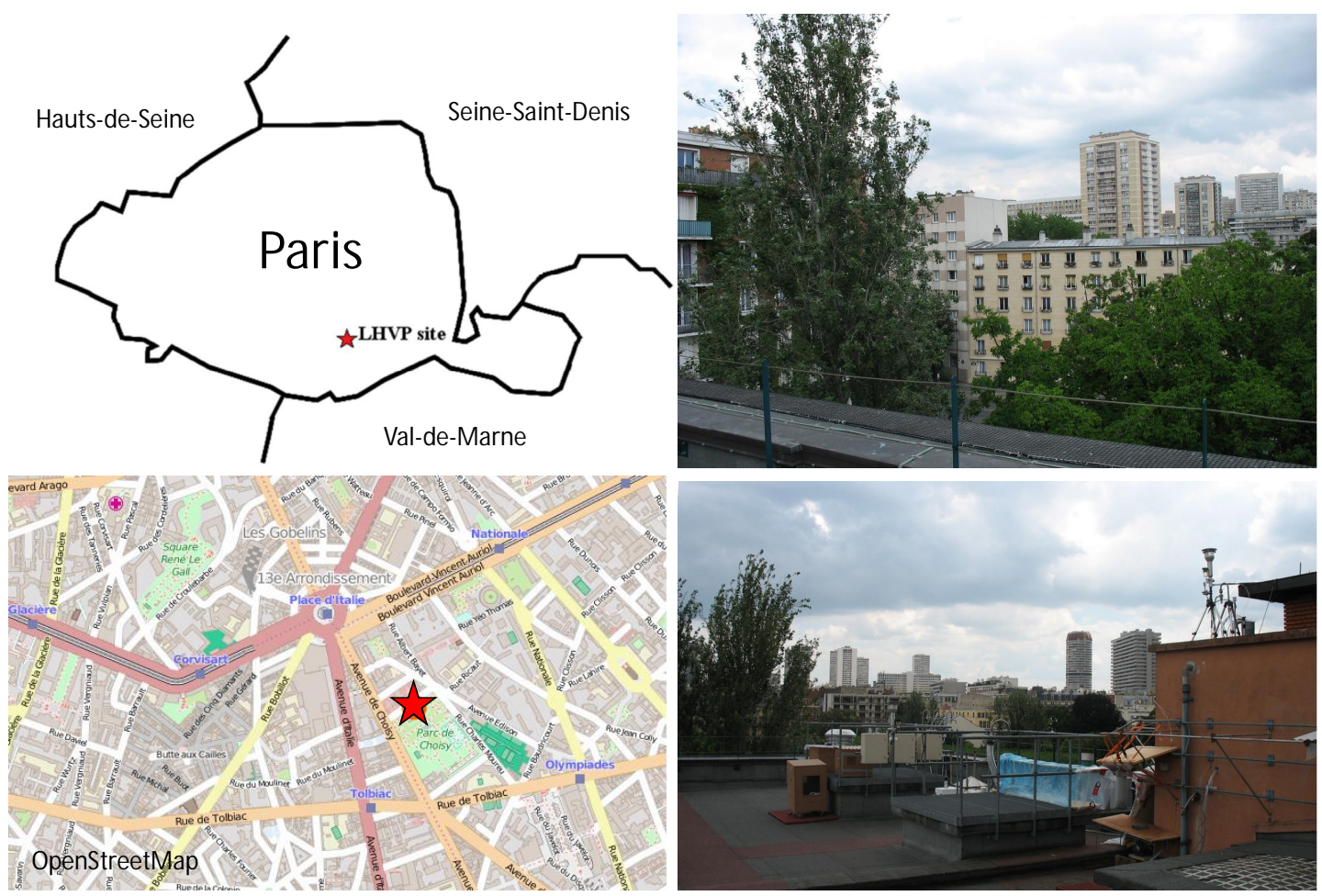

Figure 1. Location of the LHVP site in Paris (on the rooftop of Laboratoire d'Hygiène de la Ville de Paris, Paris 13 arrondissement, 11 Rue George Eastman, 75013 Paris).

diameter, when converting the measured mobility to particle diameter (see Mäkelä et al., 1996).

The particle total number concentrations for the entire campaign were obtained by combining the total concentrations measured by the TDMPS (calculated from 6 to $740 \mathrm{~nm}, 1 \mathrm{~h}$ means, period: 1-31 July 2009) with the concentrations measured by the CPC $(>6 \mathrm{~nm}, 1 \mathrm{~h}$ means, period: 11 August 2009-4 October 2010). Total concentrations below $100 \mathrm{~cm}^{-3}$ were considered invalid as these values are unrealistic for urban areas.

To analyse the behaviour of the ion population during NPF we plotted air ion size distributions as a function of time, from 27 June 2009 to 3 October 2010. Based on the plots, we classified the days into NPF events, NPF non-events, or undefined days according to the procedure described by Hirsikko et al. (2007a). NPF event days referred to days where new particle formation and growth was clearly observed for several hours; NPF non-event days comprised days of no particle formation, and undefined days referred to days in which the occurrence of NPF was unclear.

The growth rates (GR) of ions were calculated based on the maximum-concentration method described in Kulmala et al. (2012): (1) we manually selected the time of peak concentrations during NPF for each particle size range, (2) applied a Gaussian fit to the manually selected peak to determine the time of maximum concentration of that particle size range, and (3) calculated the GR by linear regression (least-squares fit) to the data points of particle size vs. time of maximum concentration.

Condensation sink (CS) was calculated based on the equations described by Dal Maso et al. (2005) using dry particle number size distributions. The approach estimates the loss rate of the condensable vapours during the change from the gas-to-particle phase (Kulmala et al., 2001). A high CS indicates the presence of large number of aerosol particles acting as both condensing nuclei for vapours and coagulation surfaces for particles.

Months were classified into seasons as follows: winter December, January, and February; spring - March, April, and May; summer - June, July, and August; autumn - September, October, and November. The air ion data were originally averaged every $3 \mathrm{~min}$; however, as the particle number data from the TDMPS was provided as hourly means, to facilitate comparison the air ion data and the particle number concentration data from the CPC were also presented as hourly means. The only exceptions were Fig. 6 (a, b, c, d) and Appendix Fig. A2, where the air ion data were shown in the original format (3 min means). Moreover, all the data in this study were presented at UTC (Paris local time: UTC $+1 \mathrm{~h}$ in the winter, and UTC $+2 \mathrm{~h}$ in the summer), and when calculating concentrations on workdays and weekends, national holidays were classified as weekends. 


\section{Results and discussion}

\subsection{Concentrations of ions and particles at the LHVP site}

The median of the daily means, and the median of the hourly means of particle number concentration in the LHVP were $12900 \mathrm{~cm}^{-3}$ (data not shown) and $12500 \mathrm{~cm}^{-3}$ (Table 1), respectively. Aalto et al. (2005) and Puustinen et al. (2007) observed daily medians of particle number concentrations ranging from 9000 to $38500 \mathrm{~cm}^{-3}$ (both studies combined) in urban background sites of European cities, including Augsburg, Stockholm, Helsinki, Amsterdam, Birmingham, Athens, Barcelona, and Rome. The mean particle number concentrations in urban and suburban areas of São Paulo, Nanjing, and Beijing were 23 500, 23 000, and 23 900-32 $800 \mathrm{~cm}^{-3}$ (combined studies), respectively (Backman et al., 2012; Herrmann et al., 2014; Wu et al., 2008; Wang et al., 2013). Thus, particle number concentrations in Paris (LHVP) were in range with the daily medians of other European cities and were lower roughly by a factor of 2 (mean: $13700 \mathrm{~cm}^{-3}$ ) compared to busy cities of other continents. Pikridas et al. (2015) evaluated mean particle number concentrations during the summer and winter in the LHVP site and reported similar concentration for particles of 10-500 nm (mean of both seasons: $13500 \mathrm{~cm}^{-3}$ ). In general, particle number concentrations tend to vary considerably among cities due to differences in meteorology, spatial and temporal distribution of local sources, emission-cleaning technologies, and air quality regulations.

The mean number concentrations of small ions at the LHVP site were 330 and $390 \mathrm{~cm}^{-3}$ for positive and negative polarities, and are close to the lower range reported in the review by Hirsikko et al. (2011) for sites around the world, $200-2500 \mathrm{~cm}^{-3}$. Shortly after their formation the small ions are removed from the air by ion-recombination and by coagulation with larger particles. Thus in polluted environments, where the load of aerosol particles is high (leading to high condensation sink), the concentrations of small ions are often lower than in cleaner environments (Hirsikko et al., 2011, and references therein; Tiitta et al., 2007; Hirsikko et al., 2007b).

In Nanjing, China, the total concentration of small ions, aerosol particles and CS were $840 \mathrm{~cm}^{-3}$ (sum of polarities), $23000 \mathrm{~cm}^{-3}$ and $5.4 \times 10^{-2} \mathrm{~s}^{-1}$, respectively (Herrmann et al., 2014). Considering only the period of July 2009 and 15 January/15 February 2010, when CS calculations were possible, the mean small ion concentrations, particle number, and CS in LHVP were $800,14460 \mathrm{~cm}^{-3}$ and $1.43 \times 10^{-2} \mathrm{~s}^{-1}$, respectively. The small ion concentrations in Nanjing were similar to that of the LHVP despite the considerably higher particle total number and CS in Nanjing. The large particle surface area acting as coagulation and condensation sinks in Nanjing should result in lower concentrations of small ions in comparison to LHVP. Since this was not observed, the re- sults suggest that Nanjing may have a higher production rate of small ions than Paris. Other studies around the world reported mean and median concentrations of small ions to be in the same range with those observed in LHVP, varying from 183 to $860 \mathrm{~cm}^{-3}$ for positive and $151-720 \mathrm{~cm}^{-3}$ for negative ions near traffic and in urban background of cities such as Athens (Greece), Kuopio (Finland), Helsinki (Finland) and Brisbane (Australia) (Retalis et al., 2009; Tiitta et al., 2007; Hirsikko et al., 2007b; Ling et al., 2013).

The concentrations of intermediate ions were in general very low. Intermediate ions were mostly present on NPF event days in comparison to NPF non-event days (Sect. 3.5). The mean concentrations of intermediate ions during the whole campaign were $20-30 \mathrm{~cm}^{-3}$ per polarity, and were similar to the annual mean observed by Tammet et al. (2014) in the city of Tartu, Estonia, $35-40 \mathrm{~cm}^{-3}$ (per polarity), but roughly half of that observed by Tiitta et al. (2007) (40$70 \mathrm{~cm}^{-3}$ per polarity) near a road in Kuopio, Finland. One explanation for the higher concentrations in Kuopio could be the proximity of the road, as some studies (Jayaratne et al., 2010; Ling et al., 2013; Ling et al., 2010; Lee et al., 2012) reported ion concentrations near traffic to be higher than in sites away from traffic.

The median concentrations of positive and negative large ions were 410 and $270 \mathrm{~cm}^{3}$, respectively. In Helsinki, Hirsikko et al. (2007b) reported weekday median concentrations of large ions $(10-40 \mathrm{~nm})$ of 510 and $540 \mathrm{~cm}^{-3}$ for positive and negative polarities, respectively. When the hourly data were segregated into workdays and weekends, the weekday concentrations of large ions $(10-40 \mathrm{~nm})$ were 1220 and $850 \mathrm{~cm}^{-3}$, for positive and negative polarity, thus considerably higher than the observations in Helsinki. As the concentrations of large ions are influenced by traffic-related aerosols (Hirsikko et al., 2007b; Tiitta et al., 2007), the difference in large ion concentrations could be due to a larger number of sources of aerosol particles, i.e. vehicle emissions, in LHVP surroundings in comparison to Helsinki.

In July $2009,41 \%$ of the total particles in the size range of 3-23 nm were comprised of naturally charged particles (sum of positive and negative polarities). The month-to-month median concentrations of ions from 0.8 to $42 \mathrm{~nm}$ varied between 1000 and $2000 \mathrm{~cm}^{-3}$ per polarity (data not shown).

Figure A1 shows correlations between particle number and ions. Particle number correlated the highest with large ions of both polarities $(r=0.58-0.61, p<0.01)$ as expected, since it is very likely that these aerosol particles were in charge balance most of the time (aerosol particles quickly attach to ions forming large ions). Weak or no correlation was found between particle number and small or intermediate ions $(r<|0.18|, p<0.01)$. Accumulation mode aerosol particles that have large surface area (thus creating high condensation sinks) and small ions are often negatively associated as the first act as sink for the latter. Aerosol particles in urban areas are mainly originated from human activities 
such as traffic, while small ions are originated from natural ionizing radiation, hence the weak correlation.

\subsection{Diurnal cycles and number size distributions of ions}

Figure 2 shows the diurnal variations of ions and particle number concentrations. On workdays, particle number concentrations peaked in the morning (07:00-08:00) and in the evening (19:00-20:00) (Fig. 2g) reflecting traffic rush hours. This pattern was consistent with the findings of Pikridas et al. (2015) in Paris during summer and winter. The evening peak was fairly constant regardless of the day, whereas the morning peak on workdays was about $50-60 \%$ higher than on the weekends, when traffic intensity is generally lower. The constant presence of an evening peak suggests constant nocturnal activities in the area, e.g. traffic and/or cooking emissions from restaurants as suggested by Freutel et al. (2013). A decrease in boundary layer mixing height also plays a role in accumulating air pollutants in the evening due to poor dilution, as suggested by Pikridas et al. (2015). Cimini et al. (2013) shows that the mixing height of the boundary layer in 15 August 2011 in SIRTA, a site $20 \mathrm{~km}$ away from LHVP, increased at 08:00 and decreased at 18:00 (UTC), roughly the time when the evening peak begins.

Large ions had maximum median concentrations of 400$600 \mathrm{~cm}^{-3}$ per polarity and a diurnal cycle very similar to that of particle number (Fig. 2e-f), undergoing an abrupt increase from the night to the morning rush hours and from weekends to workdays. As traffic produces aerosol particles, the concentrations of large ions are likely resulting from the coagulation between neutral aerosol particles and small or intermediate ions. Because busy intersections were located about $400 \mathrm{~m}$ away, it is possible that particulate traffic emissions from the intersections enhanced concentrations of large ions in LHVP. Note that as the instruments measuring particle number and ions overlap from 6 to $20 \mathrm{~nm}$, some of the intermediate and all of the large ions were also detected by the CPC. If we compare the diurnal cycle of particle number concentrations to that of large ions (sum of polarities), the latter comprised about $5.5 \%$ of the total particle number concentrations (in 6-20 nm size range) in the morning of workdays.

Small ion number concentrations of both polarities peaked early in the morning (Fig. 2a-b) and decreased during the day in agreement with some studies reviewed by Hirsikko et al. (2011). The higher concentrations on early mornings may be attributed to both the accumulation of ionizing radiation from radon decay, as the boundary layer mixing height is usually lower before sunrise (Hirsikko et al., 2011), and the lower condensation sinks early in the mornings (Fig. A3), which decrease the removal rate of small ions.

On workdays, the peak median number concentrations of small ion were between 380 and $430 \mathrm{~cm}^{-3}$ per polarity. On weekends, the number concentrations of small ions were slightly higher $\left(400-490 \mathrm{~cm}^{-3}\right)$ and the elevated concentrations of positive small ions lasted a few hours longer than on workdays, indicating that the production rate of small ions (i.e. from radon radiation) was similar throughout the week but the removal rates were lower on weekends (lower level of coagulation sink). The simultaneous decrease in small ion concentrations and increase in large ion concentrations and particle number (Fig. $2 \mathrm{e}-\mathrm{g}$ ) suggests that part of the small ion population was lost by attachment to aerosol particles as observed in previous studies (Hirsikko et al., 2007b; Jayaratne et al., 2014). The concentrations of positive small ions in the mornings of workdays (07:00) were about $26 \%$ lower in comparison to the mornings of weekends (07:00) indicating that this fraction may have been lost by coagulation to pre-existing aerosol particles.

The median number concentrations of intermediate ions (Fig. 2c-d) were low and were considerably different from the mean indicating a large variability. On workdays, the median concentrations of positive intermediate ions showed two peaks (04:00-05:00 and 12:00-13:00), while in the weekends only one shallow peak was observed. The decrease in concentrations of intermediate ions in the mornings of workdays between 06:00 and 08:00 coincided with the peak in particle number and CS (Figs. 2 and A3), indicating that coagulation sinks from traffic emissions scavenged the intermediate ions. On weekends, with the decrease in the number of aerosol particles, the number concentrations of intermediate ions remained elevated for several hours. Thus, NPF along with the decrease of particle number concentrations (condensation sinks) in the afternoon enhanced concentrations of intermediate ions around 12:00-13:00. As intermediate ions are directly associated to NPF, the results indicate that NPF was more likely to occur on weekends than on workdays in LHVP. Negative intermediate ions showed a similar diurnal cycle as the positive intermediate ions, only with lower concentrations. Despite the effects of traffic on the ion number concentrations, traffic intensity did not seem to influence the median ion size distribution (Fig. A2) in agreement with Tiitta et al. (2007).

Studies near busy roads (10-100 m away) in Finland reported that traffic emissions caused a decrease in small ion concentrations and an increase in both intermediate and large ions (Hirsikko et al., 2007b; Tiitta et al., 2007) which agrees with our results for small and large ions but disagree for intermediate ions. In Helsinki, the weekday diurnal peak concentrations of small, intermediate, and large ions were roughly $750-900,80-90$ and $950-1000 \mathrm{~cm}^{-3}$, respectively per polarity. The number concentrations were thus higher in Helsinki despite similar CS range between the sites (Helsinki: 1$50 \times 10^{-3} \mathrm{~s}^{-1}$, LHVP: $1.7-51 \times 10^{-3} \mathrm{~s}^{-1}$ ). The discrepancy is likely caused by higher radon decay and gamma radiation emissions rates from soils in Helsinki. The World Health Organization estimates higher levels of indoor radon emissions in Finland $\left(120 \mathrm{~Bq} \mathrm{~m}^{-3}\right)$ than in several other European countries, including France $\left(89 \mathrm{~Bq} \mathrm{~m}^{-3}\right)$ (WHO, 2009). 



Figure 2. Diurnal cycle of particle number concentrations $(>6 \mathrm{~nm})(\mathrm{g})$, and small $(0.8-2 \mathrm{~nm})$, intermediate $(2-7 \mathrm{~nm})$, and large ions $(7-$ $20 \mathrm{~nm})(\mathbf{a}-\mathbf{f})$ for workdays and weekends. The markers show the hourly median concentrations and the whiskers show 25 th and 75 th percentiles. The dashed lines represent mean concentrations, and the rectangles (06:00-09:00) indicate the morning peak of particle number.

In addition to differences in radon emission rates, the sizeclassification of intermediate and large ions in Hirsikko et al. (2007b) (3-10 and 10-40 nm, respectively) was different than our classification, which could explain the larger concentrations. Also the study in Helsinki was developed in the summer while ours represents an average of all seasons.

\subsection{Seasonal variations of ions and particles}

The number concentrations of small ions of both polarities (Fig. 3a) were the highest in the summer and autumn (maxima between July and September, depending on the polarity, Fig. A4) and lowest in the spring. Concentrations in January and February were also relatively high. Lopez et al. (2012) measured concentrations of ${ }^{222} \mathrm{Rn}$ for 8 years in Gif-surYvette, $20 \mathrm{~km}$ away from the LHVP site, and reported the highest radon concentrations in autumn and the lowest in the summer/spring. As radon and gamma radiations are major sources of small ions in continental areas (Hirsikko et al.,
2011), the seasonality of small ions is partially associated to the seasonality of radon exhalation, which depends for instance on boundary layer mixing height, presence of fog, snow coverage and soil humidity (Lopez et al., 2012). Despite the differences in altitude, Rose et al. (2013) also observed the lowest concentrations of small ions in spring in Puy de Dôme, a mountain in central France (1465 m a.s.l.). In Athens, the highest concentrations of small ions were observed in the summer (Retalis et al., 2009). As radon emissions depend on several factors, concentrations of small ions are expected to vary between sites. In addition to radon concentrations, in spring the higher frequency of NPF may also have increased the scavenging of small ions.

The median number concentrations of positive intermediate ions (Fig. 3b) varied with season showing the highest median number concentrations in spring, whereas the median number concentrations of the negative intermediate ions were lower $\left(<10 \mathrm{~cm}^{-3}\right)$ and more stable throughout the year. For positive intermediate ions, the highest monthly 

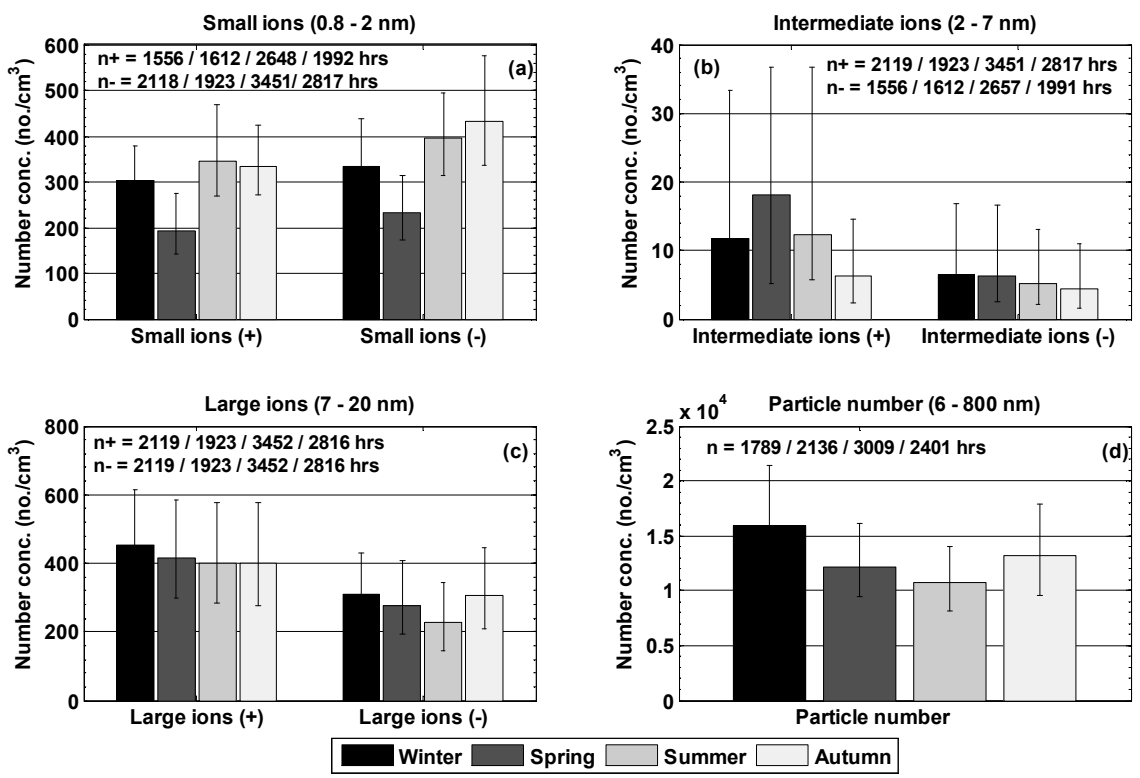

Figure 3. Seasonal variations of particle number $(\mathbf{d})$ and positive/negative ions $(\mathbf{a}-\mathbf{c})$. The bars represent median concentrations, the whiskers represent 25th and 75th percentiles, and $n( \pm)$ represents the number of hours included in each season (winter/spring/summer/autumn).

Table 1. Statistical summary of particle number concentration $(6-740 \mathrm{~nm})$, small $(0.8-2 \mathrm{~nm})$, intermediate $(2-7 \mathrm{~nm})$, and large ion (7-20 nm) number concentrations in Paris for the entire campaign. Total ions represent ions in the size range of $0.8-42 \mathrm{~nm}$ in size. Concentrations were presented as particles $\mathrm{cm}^{-3}$ and were based on $1 \mathrm{~h}$ means.

\begin{tabular}{|c|c|c|c|c|c|c|c|c|}
\hline & Mean & SD & $5 \%$ & $25 \%$ & $50 \%$ & $75 \%$ & $95 \%$ & $\begin{array}{r}\text { No. of hours } \\
\quad(1 \text { h scale })\end{array}$ \\
\hline Small ions $(+)$ & 330 & 150 & 130 & 230 & 310 & 400 & 600 & 7810 \\
\hline Small ions (-) & 390 & 180 & 160 & 270 & 360 & 470 & 740 & 7820 \\
\hline Intermediate ions $(+)$ & 30 & 40 & 0 & 0 & 10 & 30 & 100 & 10310 \\
\hline Intermediate ions (-) & 20 & 70 & 0 & 0 & 10 & 10 & 60 & 10310 \\
\hline Large ions $(+)$ & 460 & 240 & 160 & 290 & 410 & 590 & 910 & 10310 \\
\hline Large ion $(-)$ & 310 & 180 & 80 & 180 & 270 & 410 & 650 & 10310 \\
\hline Total ions $(+)$ & 1640 & 660 & 780 & 1180 & 1530 & 1980 & 2880 & 10310 \\
\hline Total ions (-) & 1270 & 540 & 590 & 900 & 1180 & 1530 & 2290 & 10310 \\
\hline Particle number concentration ${ }^{\mathrm{a}}$ & 13690 & 6430 & 5590 & 9200 & 12460 & 16840 & 26000 & 9310 \\
\hline $\mathrm{CS}_{(3-740 \mathrm{~nm})} \mathrm{b}\left(\times 10^{-3} \mathrm{~s}^{-1}\right)$ & 14.3 & 8.4 & 4.7 & 7.9 & 12.7 & 18.1 & 31.3 & 1520 \\
\hline
\end{tabular}

a Particle number: combined TDMPS (6-740 nm; 29 June 2009-31 July 2009) and CPC (dp 50 : 6 nm; 11 August 2010-4 October 2010) measurements. ${ }^{b}$ CS was calculated based on the TDMPS size distribution from 29 June 2009 to 31 July 2009 and from 15 January 2010 to 19 February 2010.

median concentrations were observed in February, March and May (peak), while for the negative polarity, the highest were observed in February, March (peak) and November (Fig. A4). The concentrations of positive intermediate ions were highly variable in July (Fig. A4), with 75th percentile reaching nearly $200 \mathrm{~cm}^{-3}$. Because intermediate ions are mostly observed during NPF events (Tammet et al., 2014) and these events have been observed to occur more often in the spring/summer around Europe (Manninen et al., 2010), high number concentrations of intermediate ions during these seasons were expected. In general, the results suggest that positive intermediate ions were more affected by seasonality than the negative intermediate ions.

The number concentrations of positive large ions were also fairly stable throughout the seasons (between 400 and $450 \mathrm{~cm}^{-3}$ ), whereas the number concentrations of negative large ions were less stable (between 230 and $310 \mathrm{~cm}^{-3}$ ) showing lowest in the summer and highest in the winter and autumn (Fig. 3c), resembling the seasonal variations of particle number (Fig. 3d). Aalto et al. (2005) showed that in several European cities particle number concentrations were highest in the winter and lowest in the summer, in agreement with our study. Pikridas et al. (2015), also reported this pat- 


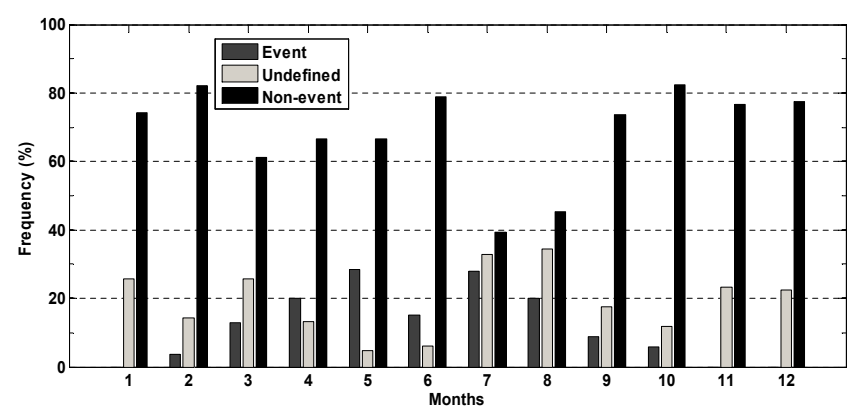

Figure 4. Monthly frequency (\%) of NPF events, NPF non-events and undefined days. Data collected continuously from July 2009 to September 2010.

tern for Paris and surrounding areas. The lower mixing height of the boundary layer and the need for heating are possible drivers for the increase in particle number concentrations in the winter.

\subsection{Frequency of NPF events}

To analyse new particle formation events we classified days into NPF event, NPF non-event, and undefined as described in Hirsikko et al. (2007a). The monthly frequency of NPF events in LHVP is shown in Fig. 4 as percentage of NPF events per number of days. On average, NPF events occurred between February and October, being most frequent in the spring and summer (highest in May and July) and least frequent in the winter. Undefined and NPF non-event days on the other hand occurred throughout the year. Manninen et al. (2010) analyzed NPF based on ion concentrations in 12 European sites and reported that several sites showed the highest frequency of NPF event days in spring/summer and minimum in the winter, in agreement with our study. Studies from urban areas such as Helsinki, Budapest, Beijing, and Pittsburgh also reported high incidence of NPF in spring (Salma et al., 2011; Hussein et al., 2008; Wu et al., 2007; Stanier et al., 2004). Pikridas et al. (2015) also observed considerably higher frequency of NPF events in the summer than in the winter in Paris and in two surrounding suburban sites.

The higher incidence of solar radiation favours photochemical reactions in the atmosphere in spring and summer which may consequently increase, the frequency of NPF, as observed by Pikridas et al. (2015). In addition to meteorological conditions, the air in LHVP and in several other sites in Europe is cleaner in the summer than in the winter (Aalto et al., 2005; Pikridas et al., 2015). Thus, NPF was likely favoured by fewer aerosol particles acting as condensation sinks (Salma et al., 2011; Wu et al., 2007; Stanier et al., 2004; Pikridas et al., 2015) in the summer.

In our study, air ions were monitored for a total of 442 days, out of which 57 days were NPF events (about 13\%), 94 were undefined days, and 291 were NPF non-event days. In non-urban environments, NPF was observed to occur some- where between 21 and $57 \%$ of the days depending on the site (Manninen et al., 2010). In urban areas, however, NPF is expected to be less frequent due to the higher number of condensation sinks competing for condensing vapours (Hussein et al., 2008). In cities such as Nanjing (China), São Paulo (Brazil), Helsinki (Finland), Shanghai (China), Pune (India), Kanpur (India), Birmingham (UK), and Budapest (Hungary), the frequency of NPF events was between 5 and $27 \%$ (Herrmann et al., 2014; Backman et al., 2012; Hussein et al., 2008; Du et al., 2012; Leng et al., 2014; Xiao et al., 2015; Kanawade et al., 2014; Zhang et al., 2004; Salma et al., 2011) which is within range of the observations in Paris $(13 \%)$. However, NPF frequencies as high as 40-55\% were observed in Beijing (China), Pittsburgh (USA), Brisbane (Australia), and Nanjing (Wu et al., 2007, 2008; Stanier et al., 2004; Crilley et al., 2014; Yu et al., 2015), although not all the studies comprised an entire year of measurements.

\subsection{Diurnal cycle of ions during new particle formation}

Figure 5 shows the differences in diurnal cycles of ions and particles on NPF events and NPF non-event days. In this section, only strong NPF events were considered (21 NPF event days). On NPF event days, a clear peak was observed between 09:00 and 11:00 (UTC) for intermediate ions and at 12:00-14:00 for large ions and particle number, whereas on NPF non-event days these "noon" peaks were completely absent. As NPF is often observed at noon, an increase in concentrations around this time was expected. The time-lag in peak concentrations between intermediate and large ions was likely caused by growth of intermediate ions. During NPF, the highest increase in concentrations occurred for intermediate ions, with median maxima of $50-80 \mathrm{~cm}^{-3}$ (10:00-11:00), about 8.5-10 times higher than on the same hour of NPF nonevent days, depending on the polarity. Because the median concentrations of intermediate ions were very low on NPF non-event days $\left(<12 \mathrm{~cm}^{-3}\right)$, the results suggest that intermediate ion concentrations may be used as indicator for NPF events in Paris. The median particle number and large ion concentrations increased 1.2 times (12:00) and 1.5-1.8 times (12:00-13:00), respectively, on NPF event days in comparison to the same hour on NPF non-event days. Thus, despite its relatively low frequency $(13 \%)$, NPF was an important source for intermediate ions, large ions and particles in Paris around noon. In cities such as Pittsburgh, USA, where the frequency of NPF events is high (50\%) (Stanier et al., 2004), particle number concentrations roughly doubled during NPF bursts $\left(45000 \mathrm{~cm}^{-3}\right)$ in comparison to the morning rush hours of workdays $\left(23000 \mathrm{~cm}^{-3}\right)$. The authors estimate that the particle number daily averages on NPF event days was about $40 \%$ higher than on NPF non-event days. In LHVP, the mean of the daily mean concentrations on event days $\left(11744 \mathrm{~cm}^{-3}\right)$ was in fact lower than on NPF non-event days $\left(14259 \mathrm{~cm}^{-3}\right)$ probably due to the lower concentrations of aerosol particles in the mornings of NPF event days. 

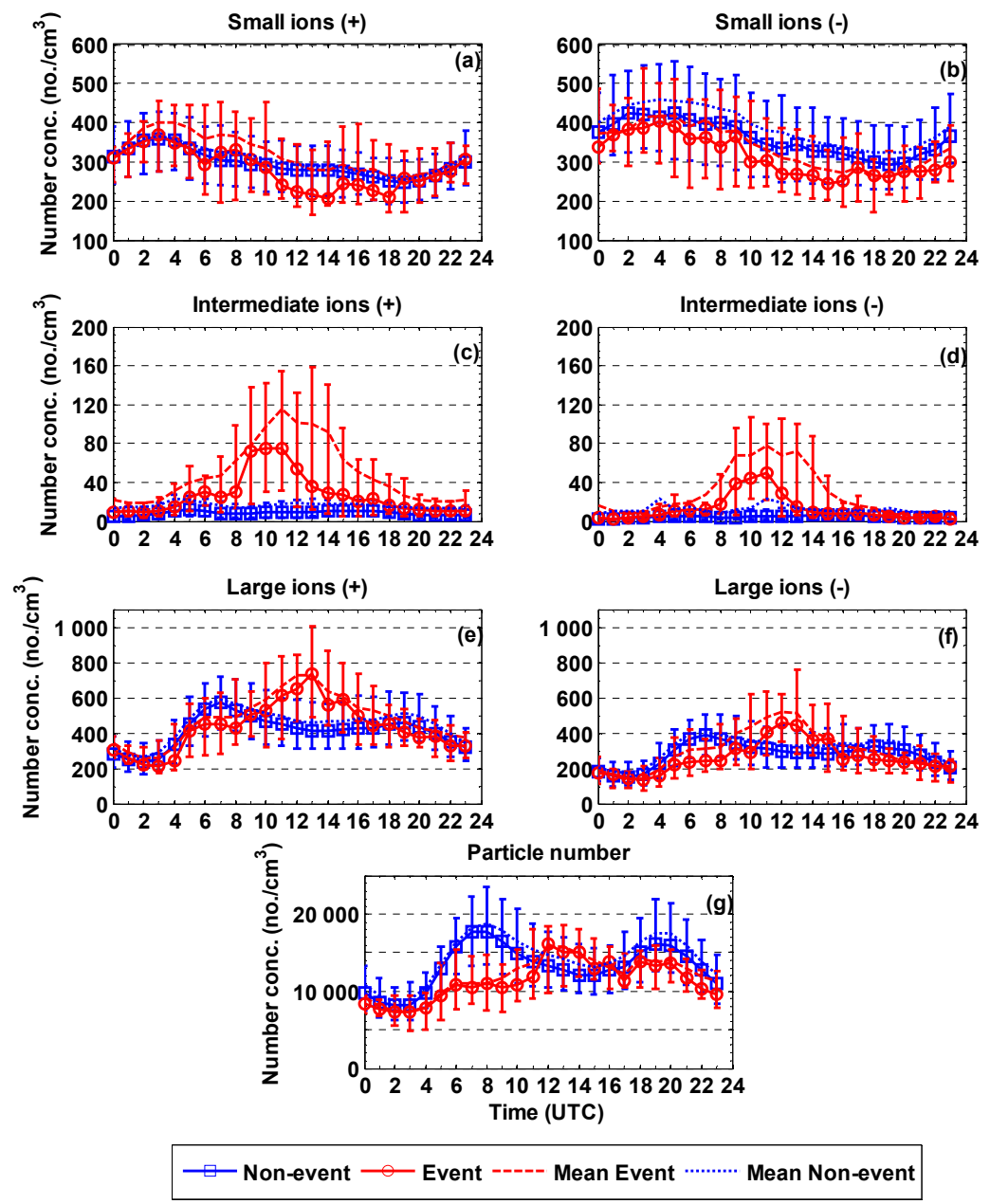

Figure 5. Diurnal cycle of aerosol particles and ions (small: $0.8-2 \mathrm{~nm}$; intermediate: $2-7 \mathrm{~nm}$; large: 7-20 nm) on strong NPF event days and NPF non-event days. The markers show the hourly median number concentrations and the whiskers show 25 th and 75 th percentiles $(1 \mathrm{~h}$ data points).

As mentioned, in the morning of event days the concentrations of large ions and especially aerosol particles (Fig. 5eg) were lower than on NPF non-event days, which may have favoured NPF. This result is consistent with the idea that NPF can be favoured on weekends due to the lower condensation sink. The cleaner atmospheric conditions illustrated in Fig. 5 could have been caused for instance by enhanced turbulent vertical mixing on NPF days (Nilsson et al., 2001). According to Wehner et al. (2010) and Nilsson et al. (2001) a higher vertical mixing could favour NPF not only by increasing the dilution of condensation sinks in the atmosphere, but also by mixing condensable vapours with cooler air from higher altitudes, thus increasing supersaturation, or even by transporting clusters formed at higher altitudes downwards.

New particle formation did not affect the small ion concentrations as much as it did the other particle sizes. On event days, the concentrations of positive small ions decreased roughly around noon in comparison to NPF non-event days, indicating scavenging of these ions by the newly formed particles. This decrease around noon was also observed for negative small ions; however, the number concentrations of these ions were in general slightly lower on NPF event days in comparison to NPF non-event days. Winkler et al. (2008) indicates that ion-induced nucleation is formed preferably onto negative ions, thus, the decrease in negative small ion concentrations could indicate that part of these ions were used during ion-induced nucleation. Yet, we only observed a weak positive correlation $(r=0.10$ to $0.25, p<0.01)$ between intermediate and small ions (Fig. A5). In general, no clear correlation between NPF (intermediate ion/small ions) and small ions or particle number was observed (Fig. A6).

\section{Case study of four NPF event days}

We selected four NPF event days of various intensities and duration to observe the behaviour of ions and aerosol parti- 


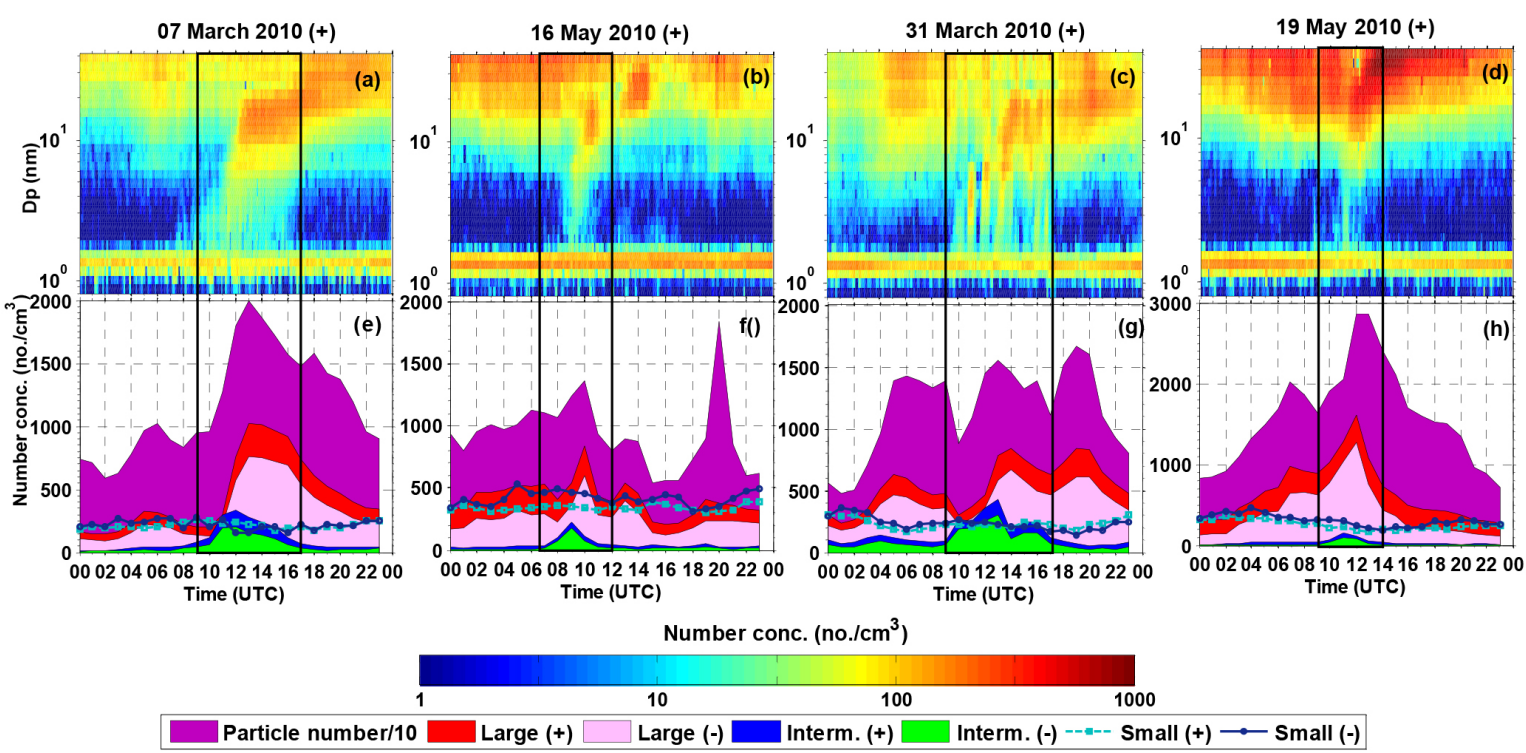

Figure 6. Examples of NPF event days observed in the LHVP site. The first row of figures represent positive ions measured using AIS (dp: $0.8-42 \mathrm{~nm}$ ) with a time resolution of $3 \mathrm{~min}$. The second row represents mean number concentrations of particle total number ( $>6 \mathrm{~nm}$ ), small $(0.8-2 \mathrm{~nm})$, intermediate $(2-7 \mathrm{~nm})$, and large ions $(7-20 \mathrm{~nm})$, at a resolution of $1 \mathrm{~h}$. Note that absolute particle number concentration is obtained by multiplying the concentrations by 10 . The black rectangles indicate the NPF bursts.

cles during the bursts (Fig. 6). In all the 4 days, a "banana" shaped NPF event was observed. This type of NPF event is likely of regional nature as it requires uniform air masses to last for at least a few hours (Manninen et al., 2010). Thus, the gaps in the "bananas" (Fig. 6b-c) could be caused by some degree of heterogeneity in the regional air masses. According to Hussein et al. (2009), regional NPF events may spread for over $200 \mathrm{~km}$ and the newly formed particles may be traced for as long as $30 \mathrm{~h}$ before they merge into background levels. Pikridas et al. (2015) analyzed NPF events in LHVP and in two suburban sites near Paris, GOLF and SIRTA ( $20 \mathrm{~km} \mathrm{NE}$ and $20 \mathrm{~km}$ SE from Paris, respectively). The authors measured particle number size distributions in all the three sites during the summer of 2009 and the winter of 2010. The results showed that nearly all the NPF events observed in SIRTA in the summer were also observed in LHVP, and roughly half of these events (6 event days) were also observed at GOLF, thus covering at least $40 \mathrm{~km}$ in extension. The results by Pikridas et al. (2015) indicate that at least half of the NPF events observed in LHVP in the summer were regional in nature.

The diurnal behaviour of ions varied considerably among the 4 days. On example days, NPF started between 08:00 and 12:00 (UTC) (Fig. 6). A "pool" of small ions was observed in all the 4 days suggesting the constant presence of these ions, in agreement with previous studies (Manninen et al., 2009). No significant changes in small ion number concentrations were observed during the bursts (Fig. 6e-h). The number concentrations of intermediate ions (both polarities) however increased 4-15 times (depending on the day) dur- ing the bursts in comparison to the number concentrations immediately before the bursts, reaching mean values as high as $420 \mathrm{~cm}^{-3}$ (positive polarity) on the 31 March 2010. For large ions the concentrations were 1.8-6 times higher during the bursts, and for particle number concentrations it was 1.32 times higher (depending on the day). On the 19 May 2010, particle number reached $28600 \mathrm{~cm}^{-3}$ during the NPF burst (13:00), a value considerably higher than the mean concentrations observed in the morning rush hours of workdays (Fig. $2 \mathrm{~g}: 19500 \mathrm{~cm}^{-3}, 08: 00$ ). Once again, during the NPF events the concentrations of large ions and particle number peaked about $1 \mathrm{~h}$ later than that of intermediate ions, indicating growth. Hence, the results confirm that NPF events can considerably increase the number concentration of intermediate ions $(2-7 \mathrm{~nm})$, large ions $(7-20 \mathrm{~nm})$, and aerosol particles in the urban air.

\section{Growth rates of ions}

Particles growth rate (GR) is proportional to the concentrations of condensing vapours in the air. We calculated GR for ions in diameters of $1.9-3,3-7$, and 7-20 nm. A total of 21 strong NPF events were used in the calculations, 9 of which were workdays and 12 were weekends. Thus, the results once again suggest that NPF (in this case strong NPF events) may be favoured on weekends due to the lower load of condensation sinks. In general, the GR of ions (Table 2) increased with ion size (median: $1.9-3 \mathrm{~nm}: 3.4 \mathrm{~nm} \mathrm{~h}^{-1} ; 3-7 \mathrm{~nm}: 5.9 \mathrm{~nm} \mathrm{~h}^{-1}$; $\left.7-20 \mathrm{~nm}: 6.9 \mathrm{~nm} \mathrm{~h}^{-1}\right)$ in agreement with previous studies, including urban areas (Yli-Juuti et al., 2011; Manninen et al., 
Table 2. Growth rates of ions (mean of positive and negative) calculated from 21 NPF event days (9 workdays and 12 weekends). The total growth rates $\left(\mathrm{GR}_{\mathrm{tot}}\right)$ include both workdays and weekends. The unit for GR is $\mathrm{nm} \mathrm{h}^{-1}$. The CS calculations were based on TDMPS data from Jul 2009 and January/February 2010 (hourly means).

\begin{tabular}{lrrrrrrr}
\hline & Mean & $5 \%$ & $25 \%$ & $50 \%$ & $75 \%$ & $95 \%$ & No. days \\
\hline GR $_{\text {tot }}(1.9-3 \mathrm{~nm})$ & 4.0 & 1.3 & 2.5 & 3.4 & 5.7 & 7.4 & 21 \\
GR $_{\text {tot }}(3-7 \mathrm{~nm})$ & 7.6 & 1.9 & 3.9 & 5.9 & 9.1 & 24.1 & 21 \\
GR tot $(7-20 \mathrm{~nm})$ & 8.5 & 4.0 & 6.3 & 6.9 & 10.8 & 17.6 & 21 \\
\hline Workdays & & & & & & & \\
\hline GR $(1.9-3 \mathrm{~nm})$ & 4.1 & 2.1 & 2.8 & 3.4 & 5.7 & 6.9 & 12 \\
GR $(3-7 \mathrm{~nm})$ & 7.1 & 3.1 & 4.4 & 6.8 & 9.3 & 12.2 & 12 \\
GR $(7-20 \mathrm{~nm})$ & 8.8 & 6.4 & 6.8 & 8.0 & 9.1 & 16.5 & 12 \\
CS $(3-740 \mathrm{~nm})\left(\times 10^{-3} \mathrm{~s}^{-1}\right)$ & 14.9 & 5.2 & 8.5 & 13.1 & 18.5 & 33.2 & 51 \\
\hline Weekends & & & & & & & \\
\hline GR $(1.9-3 \mathrm{~nm})$ & 3.9 & 1.0 & 2.1 & 3.3 & 5.5 & 7.9 & 9 \\
GR $(3-7 \mathrm{~nm})$ & 8.0 & 1.7 & 3.2 & 5.0 & 8.4 & 28.4 & 9 \\
GR $(7-20 \mathrm{~nm})$ & 8.3 & 3.6 & 4.5 & 6.5 & 11.6 & 18.6 & 9 \\
CS $(3-740 \mathrm{~nm})\left(\times 10^{-3} \mathrm{~s}^{-1}\right)$ & 12.7 & 3.7 & 7.1 & 11.1 & 16.7 & 26.7 & 19 \\
\hline
\end{tabular}

2010; Kulmala et al., 2012, 2004b; Backman et al., 2012; Herrmann et al., 2014). The results support the theory that condensing vapours aiding the growth of ions from 3 to $20 \mathrm{~nm}$ may differ in composition from vapours aiding the growth of smaller ions, as suggested by previous studies (Manninen et al., 2010). In addition to different chemical composition, Kulmala et al. (2004b) suggests that the increase in GR with particle size could also relate to the diurnal availability of condensing vapours and Nano-Köhler effect (Kulmala et al., 2004a). If the diurnal peak in vapour concentration occurred after NPF, there would be fewer vapours available to grow the smaller particles in comparison to the larger ones (growing later). The Kelvin effect (Kulmala et al., 2004a, b; Yli-Juuti et al., 2011) and the Nano-Köhler effect (Kulmala et al., 2004a) may also influence the GR as they favour evaporation of small particles and growth of larger ones. Moreover, the median GR was higher on workdays than on weekends for ions from 3 to 7 and 7 to $20 \mathrm{~nm}$. This pattern was not as evident for ions from 1.9 to $3 \mathrm{~nm}$ nor for mean GR values.

The GR of ions from 3 to $20 \mathrm{~nm}$ were higher on workdays likely due to the higher availability of traffic-emitted condensable vapours. In cities such as São Paulo, Nanjing, and Helsinki, the reported mean GR for ions were 2.1$5.3,6.3-9.7$, and $8.0-11.4 \mathrm{~nm} \mathrm{~h}^{-1}$ for size ranges of 1-3, $3-7$, and $7-20 \mathrm{~nm}$ (7-30 $\mathrm{nm}$ in Nanjing), respectively, and were in range with the GR observed in the LHVP site (Table 2). Manninen et al. (2010) reported median GR of ions in European sites (mostly rural and coastal sites) to be $2.8 \mathrm{~nm} \mathrm{~h}^{-1}$ for particles of $1.5-3 \mathrm{~nm} ; 4.3 \mathrm{~nm} \mathrm{~h}^{-1}$ for particles of 7-20 nm, and $5.4 \mathrm{~nm} \mathrm{~h}^{-1}$ for particles of 7-20 nm, which are mostly lower than the values observed in the urban areas. Hussein et al. (2008) compared NPF characteristics be- tween Helsinki and Hyytiälä, a rural area in Finland. The authors observed higher GR in Helsinki and concluded that the higher availability of condensing vapours and the large number of aerosol particles in Helsinki probably enhanced growth by condensation and coagulation in comparison to Hyytiälä. Note that, as Hussein et al. (2008) and Yli-Juuti et al. (2011) pointed out, the GR calculation method is somewhat subjective and thus also influences GR values. Moreover, GR can also vary depending on the instruments used (Yli-Juuti et al., 2011).

The median CS concentrations were only slightly higher on workdays in comparison to weekends (Table 2) indicating that part of the particle surface area may also originate from long range transport. Sciare et al. (2010) analyzed the composition of $\mathrm{PM}_{2.5}$ in Paris and reported that the city receives polluted air masses $\left(\mathrm{PM}_{2.5}\right)$ from north-western and central Europe. Note that CS calculations were based on roughly 2 months of data, and thus are not representative of the entire campaign.

\section{Conclusions}

We analyzed frequency and seasonal variations of NPF events, diurnal and seasonal cycles of ions and aerosol particles, as well as the behaviour of ions and their growth rates during NPF events in an urban background site of Paris, France. Condensation sinks were also calculated. Our measurement period extended over 16 months: June 2009October 2010. We were especially focusing on atmospheric ions: small $(0.8-2 \mathrm{~nm})$, intermediate $(2-7 \mathrm{~nm})$, and large ions $(7-20 \mathrm{~nm})$. 
On workdays, particle number concentrations peaked in the mornings and evenings, reflecting the traffic rush hours. During the morning peak, the concentrations of small and intermediate ions decreased, whereas the concentrations of large ions increased. This indicates that aerosol particles from traffic acted as scavengers for small and intermediate ions. Both ions and aerosol particle concentrations varied with season, and these variations differed with ion polarities. Number concentrations of small ions were lowest in the spring, when number concentrations of positive intermediate ions were highest. The results thus indicate that when comparing ion concentrations from different studies, one should consider the season in which the study was conducted and also the polarity regarded.

NPF was occurred on $13 \%$ of the days (34 weekdays and 23 weekends). Seasonally, NPF occurred mainly in late spring and summer, and were completely absent from November to January. Undefined days, however, occurred throughout the year. Higher frequency of photochemical reactions along with lower number concentrations of aerosol particles may have enhanced the frequency of NPF in the summer. The growth rates of ions during NPF events increased with ion size and had median values varying between 3 and $7 \mathrm{~nm} \mathrm{~h}^{-1}$ in Paris. Moreover, the median GR's of ions were higher on workdays than on weekends for ions from 3 to $20 \mathrm{~nm}$, but this pattern was unclear for ions from 1.9 to $3 \mathrm{~nm}$ and for mean GR values. A higher GR during workdays suggests higher availability of condensing vapours in comparison to weekends.
The diurnal cycle of ions and particles during NPF events and NPF non-event days suggest that NPF was an important contributor for both ions and aerosol particles in Paris. On average, the NPF bursts caused an extra peak between 09:00 and 14:00 in the diurnal cycles of intermediate ions, large ions and particle number. The intermediateions were by far the most affected by NPF, with median concentrations increasing 8.5 to 10 times during the bursts in comparison to the same hour on NPF non-event days. Because the median number concentrations of intermediate ions were so low on NPF non-event days $\left(<12 \mathrm{~cm}^{-3}\right)$ in comparison to NPF event days $\left(50-80 \mathrm{~cm}^{-3}\right)$, the results suggest that intermediate ion number concentrations could be used as an indicator for NPF in Paris. The intermediate ions produced during the bursts grew to larger sizes on average within a few hours, increasing the median number concentrations of large ions and aerosol particles by a factor of 1.5-1.8 (depending on the polarity) and 1.2, respectively, in comparison to NPF non-event days. The results indicate that NPF in Paris was favoured on weekends, when the load of aerosol particles was lower. This idea was reinforced by the statistics of strong NPF events. Out of the 21 strong NPF events, 9 were observed on workdays and 12 were on weekends.

In general, as aerosol particles are associated to adverse health effects, the results suggest that NPF events influenced the air quality in Paris around noon (increasing the total particle number concentration, not so much the total particle mass as these are nucleation mode particle), especially during the spring and summer, when the frequency of NPF was highest. 


\section{Appendix A}
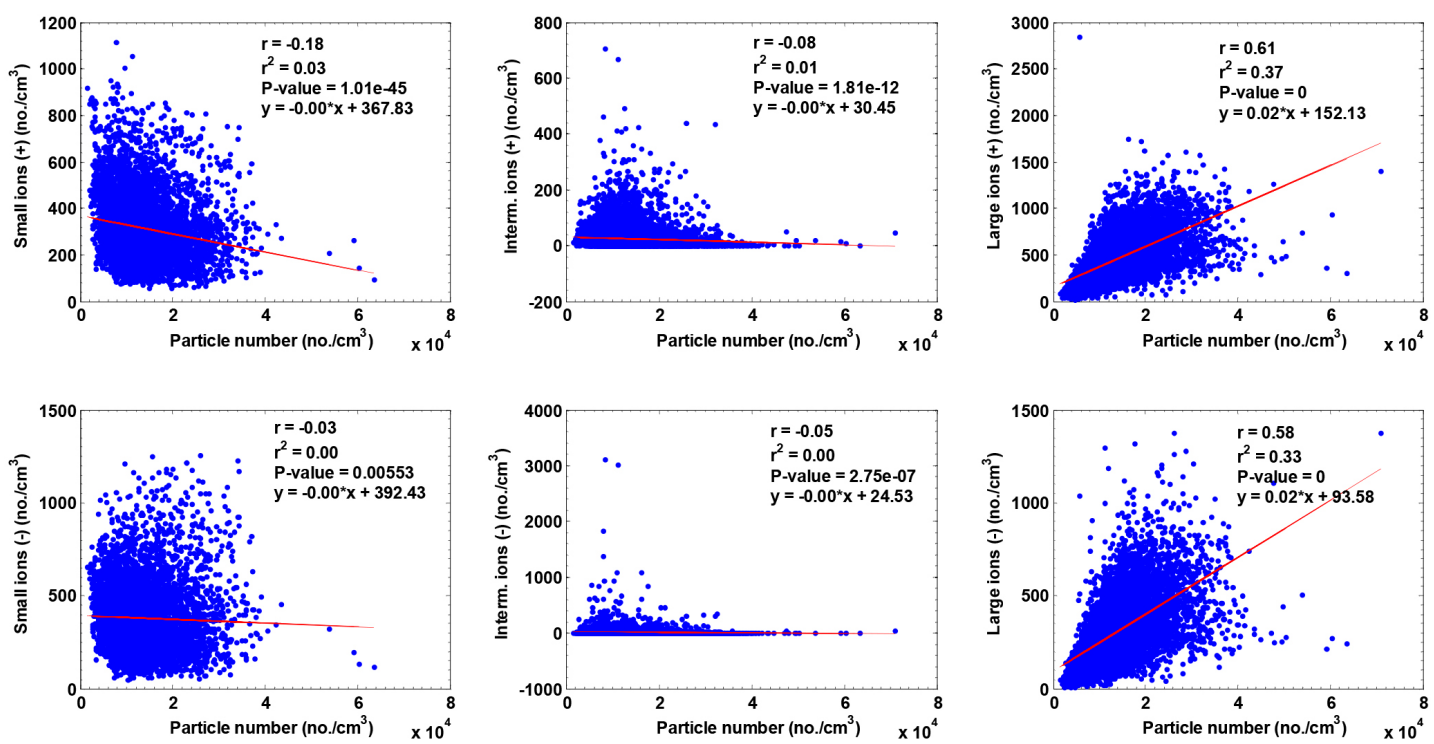

Figure A1. Correlation between particle number concentrations and ions (small: $0.8-2 \mathrm{~nm}$; intermediate: $2-7 \mathrm{~nm}$; large: $7-20 \mathrm{~nm}$ ).
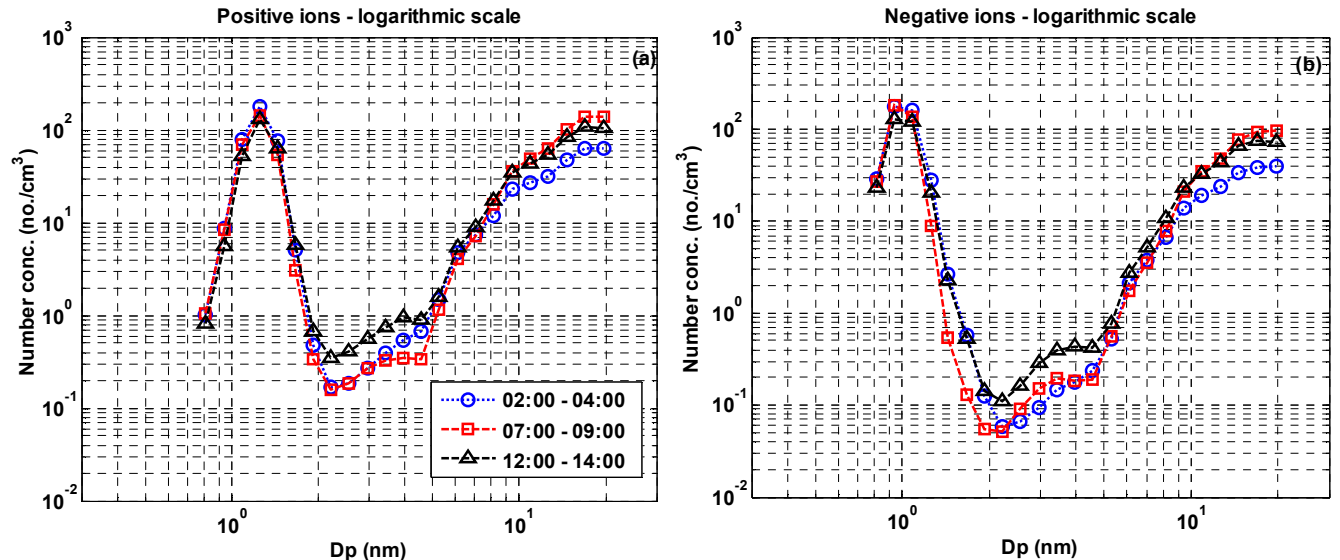

Figure A2. Median size distribution of ion on workdays: early morning (02:00-04:00), rush hours (07:00-09:00) and noon (12:00-14:00). 


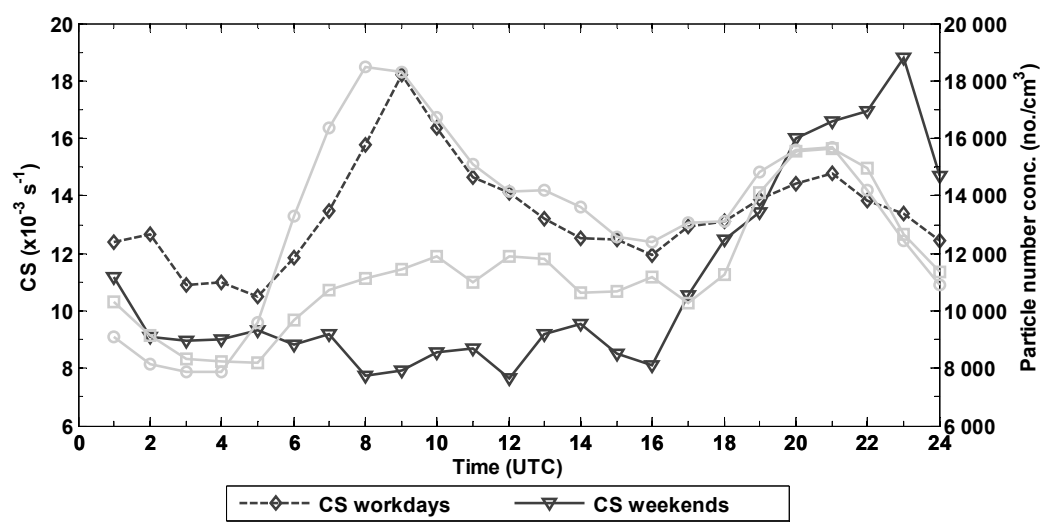

Figure A3. Diurnal cycle of condensation sink (CS) based on data from 1 to 31 July 2009 and 15 January to 15 February 2010 (1 h resolution) and particle number concentrations. The markers represents median of hourly means.
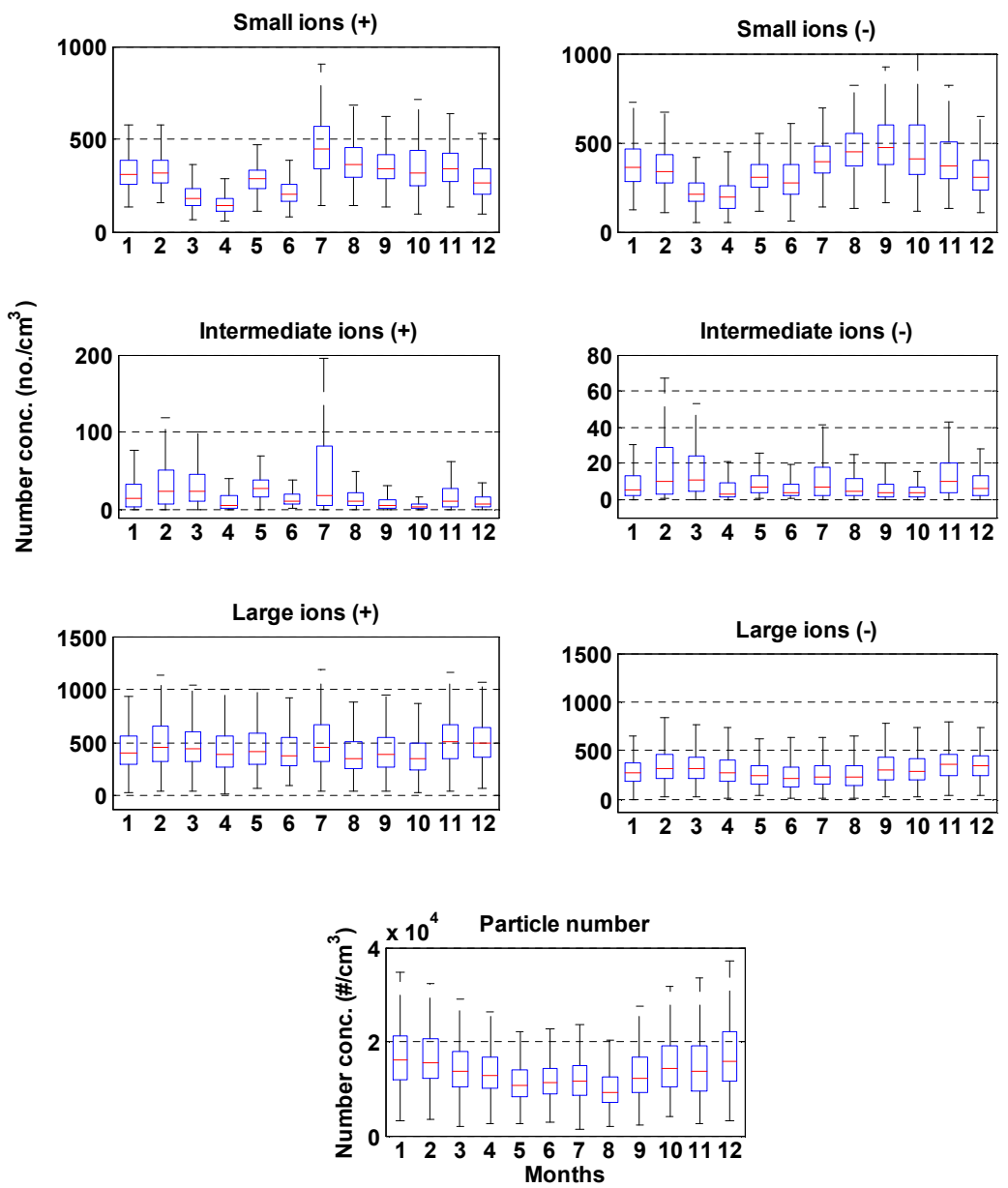

Figure A4. Monthly variations of ions and particles in Paris. The edges of the boxes represent 25 th and 75 th percentiles, the central line is the median, the whiskers represent the highest concentrations (not considered outliers). The data span the period 1 July 2009-30 September 2010. 

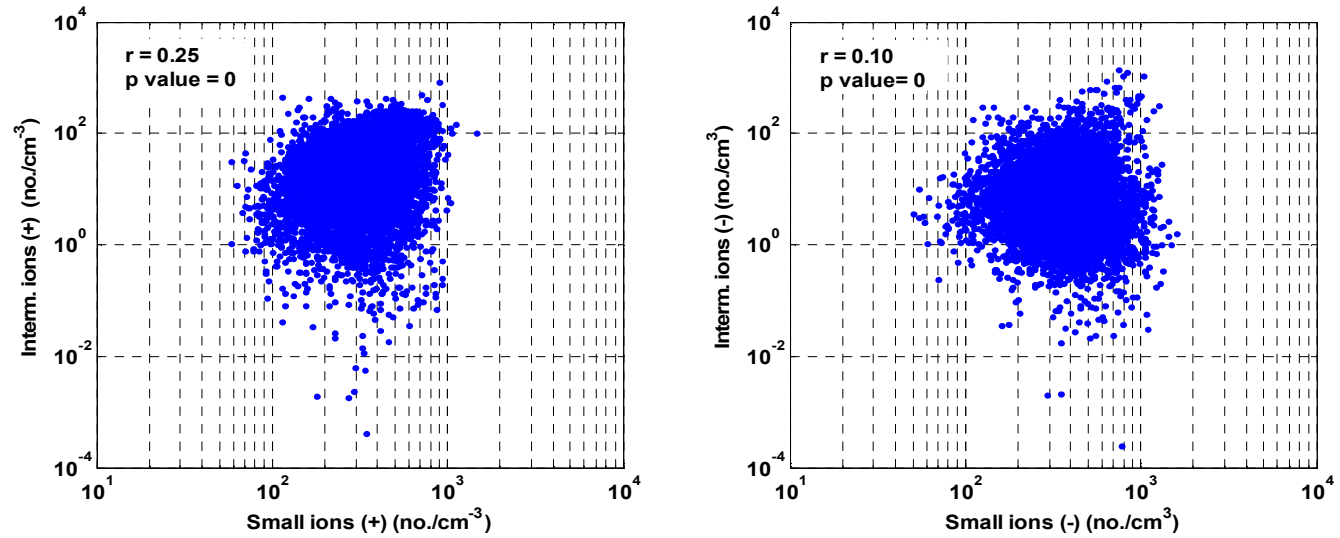

Figure A5. Correlation between intermediate ions and small ions.
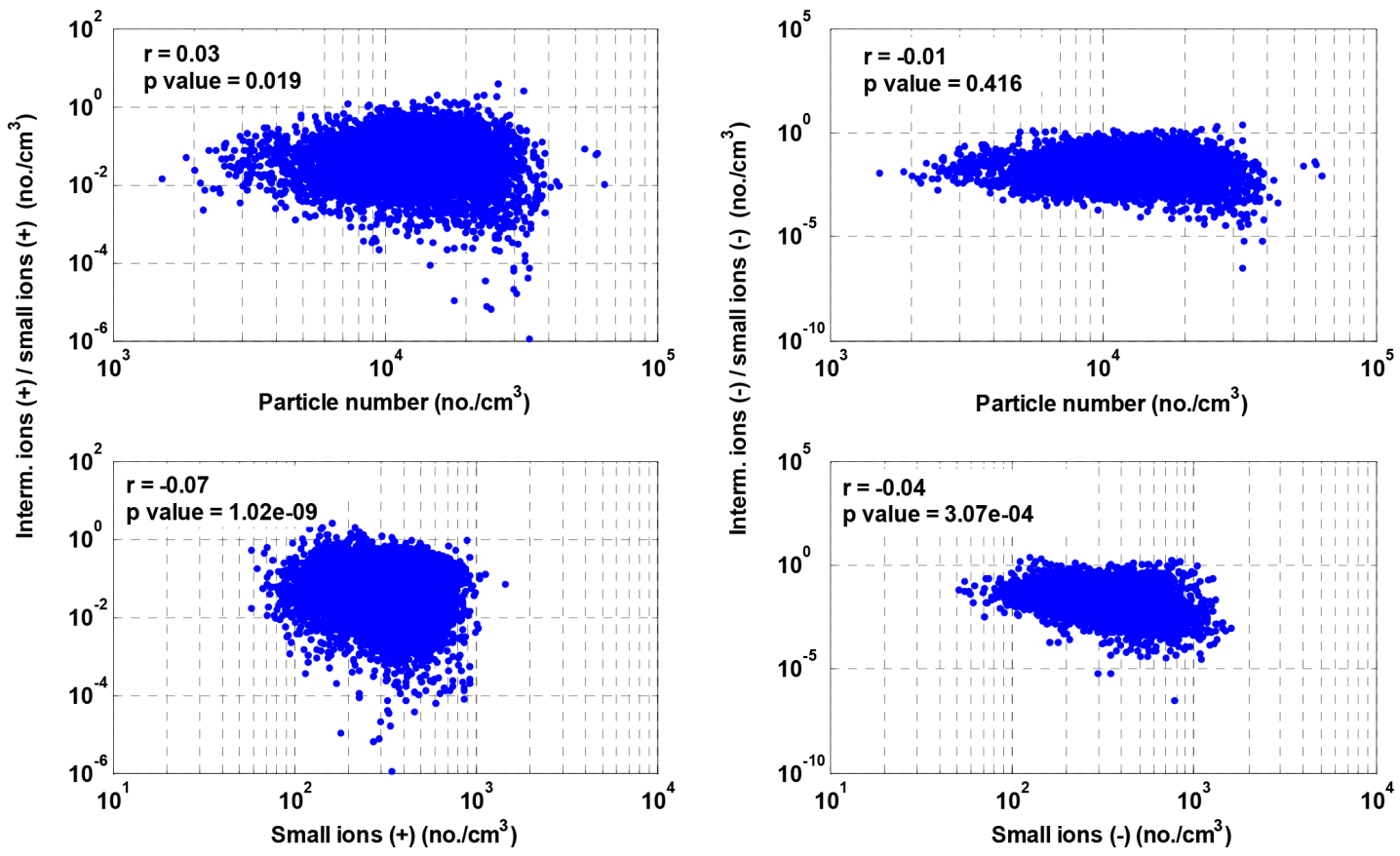

Figure A6. Correlation between the ratio intermediate ions/small ions and particle number and small ions. 
Acknowledgements. This project was partially developed in the frame of the European Union's Seventh Framework Programme FP/2007-2011 within the project MEGAPOLI (grant agreement no. 212520). We also gratefully acknowledge the support by the Academy of Finland Centre of Excellence Program (grant no. 1118615 and no. 272041), and the support by the French data centre for atmospheric chemistry, created and co-directed by CNES (the French Space Agency) and INSU-CNRS (National Institute of Sciences of the Universe) of the MEGAPOLI database. We would also like to acknowledge Katrianne Lehtipalo for her contribution on the MEGAPOLI measurements and data processing.

Edited by: M. Beekmann

\section{References}

Aalto, P., Hameri, K., Paatero, P., Kulmala, M., Bellander, T., Berglind, N., Bouso, L., Castano-Vinyals, G., Sunyer, J., Cattani, G., Marconi, A., Cyrys, J., von Klot, S., Peters, A., Zetzsche, K., Lanki, T., Pekkanen, J., Nyberg, F., Sjovall, B., and Forastiere, F.: Aerosol particle number concentration measurements in five European cities using TSI-3022 condensation particle counter over a three-year period during health effects pollution on susceptible subpopulations, J. Air Waste Manage., 55, 1064-1076, 2005.

Asmi, E., Sipilä, M., Manninen, H. E., Vanhanen, J., Lehtipalo, K., Gagné, S., Neitola, K., Mirme, A., Mirme, S., Tamm, E., Uin, J., Komsaare, K., Attoui, M., and Kulmala, M.: Results of the first air ion spectrometer calibration and intercomparison workshop, Atmos. Chem. Phys., 9, 141-154, doi:10.5194/acp-9-141-2009, 2009.

Backman, J., Rizzo, L. V., Hakala, J., Nieminen, T., Manninen, H. E., Morais, F., Aalto, P. P., Siivola, E., Carbone, S., Hillamo, R., Artaxo, P., Virkkula, A., Petäjä, T., and Kulmala, M.: On the diurnal cycle of urban aerosols, black carbon and the occurrence of new particle formation events in springtime São Paulo, Brazil, Atmos. Chem. Phys., 12, 11733-11751, doi:10.5194/acp12-11733-2012, 2012.

Cimini, D., De Angelis, F., Dupont, J.-C., Pal, S., and Haeffelin, M.: Mixing layer height retrievals by multichannel microwave radiometer observations, Atmos. Meas. Tech., 6, 2941-2951, doi:10.5194/amt-6-2941-2013, 2013..

Crilley, L. R., Jayaratne, E. R., Ayoko, G. A., Miljevic, B., Ristovski, Z., and Morawska, L.: Observations on the Formation, Growth and Chemical Composition of Aerosols in an Urban Environment, Environ. Sci. Technol., 48, 6588-6596, doi:10.1021/es5019509, 2014.

Crippa, M., DeCarlo, P. F., Slowik, J. G., Mohr, C., Heringa, M. F., Chirico, R., Poulain, L., Freutel, F., Sciare, J., Cozic, J., Di Marco, C. F., Elsasser, M., Nicolas, J. B., Marchand, N., Abidi, E., Wiedensohler, A., Drewnick, F., Schneider, J., Borrmann, S., Nemitz, E., Zimmermann, R., Jaffrezo, J.-L., Prévôt, A. S. H., and Baltensperger, U.: Wintertime aerosol chemical composition and source apportionment of the organic fraction in the metropolitan area of Paris, Atmos. Chem. Phys., 13, 961-981, doi:10.5194/acp-13-961-2013, 2013.

D'Alessandro, F.: Experimental study of the effect of wind on positive and negative corona from a sharp point in a thunderstorm, J. Electrostatics, 67, 482-487, 2009.
Dal Maso, M., Kulmala, M., Riipinen, I., Wagner, R., Hussein, T., Aalto, P. P., and Lehtinen, K. E. J.: Formation and growth of fresh atmospheric aerosols: eight years of aerosol size distribution data from SMEAR II, Hyytiala, Finland, Boreal Environ. Res., 10, 323-336, 2005.

Du, J. F., Cheng, T. T., Zhang, M., Chen, J. M., He, Q. S., Wang, X. M., Zhang, R. J., Tao, J., Huang, G. H., Li, X., and Zha, S. P.: Aerosol Size Spectra and Particle Formation Events at Urban Shanghai in Eastern China, Aerosol Air Qual. Res., 12, 13621372, doi:10.4209/aaqr.2011.12.0230, 2012.

Favez, O., Cachier, H., Sciare, J., and Le Moullec, Y.: Characterization and contribution to PM2.5 of semi-volatile aerosols in Paris (France), Atmos. Environ.t, 41, 7969-7976, doi:10.1016/j.atmosenv.2007.09.031, 2007.

Freney, E. J., Sellegri, K., Canonaco, F., Colomb, A., Borbon, A., Michoud, V., Doussin, J.-F., Crumeyrolle, S., Amarouche, N., Pichon, J.-M., Bourianne, T., Gomes, L., Prevot, A. S. H., Beekmann, M., and Schwarzenböeck, A.: Characterizing the impact of urban emissions on regional aerosol particles: airborne measurements during the MEGAPOLI experiment, Atmos. Chem. Phys., 14, 1397-1412, doi:10.5194/acp-14-1397-2014, 2014.

Freutel, F., Schneider, J., Drewnick, F., von der Weiden-Reinmüller, S.-L., Crippa, M., Prévôt, A. S. H., Baltensperger, U., Poulain, L., Wiedensohler, A., Sciare, J., Sarda-Estève, R., Burkhart, J. F., Eckhardt, S., Stohl, A., Gros, V., Colomb, A., Michoud, V., Doussin, J. F., Borbon, A., Haeffelin, M., Morille, Y., Beekmann, M., and Borrmann, S.: Aerosol particle measurements at three stationary sites in the megacity of Paris during summer 2009: meteorology and air mass origin dominate aerosol particle composition and size distribution, Atmos. Chem. Phys., 13, 933-959, doi:10.5194/acp-13-933-2013, 2013.

Gagné, S., Lehtipalo, K., Manninen, H. E., Nieminen, T., Schobesberger, S., Franchin, A., Yli-Juuti, T., Boulon, J., Sonntag, A., Mirme, S., Mirme, A., Hõrrak, U., Petäjä, T., Asmi, E., and Kulmala, M.: Intercomparison of air ion spectrometers: an evaluation of results in varying conditions, Atmos. Meas. Tech., 4, 805-822, doi:10.5194/amt-4-805-2011, 2011.

Gagné, S., Leppä, J., Petäjä, T., McGrath, M. J., Vana, M., Kerminen, V.-M., Laakso, L., and Kulmala, M.: Aerosol charging state at an urban site: new analytical approach and implications for ion-induced nucleation, Atmos. Chem. Phys., 12, 4647-4666, doi:10.5194/acp-12-4647-2012, 2012.

Gopalakrishnan, V., Pawar, S. D., Siingh, D., and Kamra, A. K.: Intermediate ion formation in the ship's exhaust, Geophys. Res. Lett., 32, 1-4, 2005.

Haverkamp, H., Wilhelm, S., Sorokin, A., and Arnold, F.: Positive and negative ion measurements in jet aircraft engine exhaust: concentrations, sizes and implications for aerosol formation, Atmos. Environ., 38, 2879-2884, 2004.

Harrison, R. G. and Carslaw, K. S.: Ion-aerosol-cloud processes in the lower atmosphere, Rev. Geophys., 41, 1012, doi:10.1029/2002RG000114, 2003.

Herrmann, E., Ding, A. J., Kerminen, V.-M., Petäjä, T., Yang, X. Q., Sun, J. N., Qi, X. M., Manninen, H., Hakala, J., Nieminen, T., Aalto, P. P., Kulmala, M., and Fu, C. B.: Aerosols and nucleation in eastern China: first insights from the new SORPES-NJU station, Atmos. Chem. Phys., 14, 2169-2183, doi:10.5194/acp14-2169-2014, 2014. 
Hirsikko, A., Bergman, T., Laakso, L., Dal Maso, M., Riipinen, I., Hõrrak, U., and Kulmala, M.: Identification and classification of the formation of intermediate ions measured in boreal forest, Atmos. Chem. Phys., 7, 201-210, doi:10.5194/acp-7-201-2007, 2007a.

Hirsikko, A., Yli-Juuti, T., Nieminen, T., Vartiainen, E., Laakso, L., Hussein, T., and Kulmala, M.: Indoor and outdoor air ions and aerosol particles in the urban atmosphere of Helsinki: characteristics, sources and formation, Boreal Environ. Res., 12, 295-310, $2007 \mathrm{~b}$.

Hirsikko, A., Nieminen, T., Gagné, S., Lehtipalo, K., Manninen, H. E., Ehn, M., Hõrrak, U., Kerminen, V.-M., Laakso, L., McMurry, P. H., Mirme, A., Mirme, S., Petäjä, T., Tammet, H., Vakkari, V., Vana, M., and Kulmala, M.: Atmospheric ions and nucleation: a review of observations, Atmos. Chem. Phys., 11, 767798, doi:10.5194/acp-11-767-2011, 2011.

Hoppel, W. A.: Ion-Aerosol Attachement Coefficients, Ion Depletion, and the Charge Distribution on Aerosols, J. Geophys. Res., 90, 5917-5923, 1985.

Hoppel, W. A. and Frick, G. M.: Ion-attachment coefficients and the steady-state charge distribution on aerosols in a bipolar ion environment, Aerosol Sci. Technol., 5, 1-21, 1986.

Hussein, T., Martikainen, J., Junninen, H., Sogacheva, L., Wagner, R., Dal Maso, M., Riipinen, I., Aalto, P. P., and Kulmala, M.: Observation of regional new particle formation in the urban atmosphere, Tellus B, 60, 509-521, doi:10.1111/j.16000889.2008.00365.x, 2008.

Hussein, T., Junninen, H., Tunved, P., Kristensson, A., Dal Maso, M., Riipinen, I., Aalto, P. P., Hansson, H.-C., Swietlicki, E., and Kulmala, M.: Time span and spatial scale of regional new particle formation events over Finland and Southern Sweden, Atmos. Chem. Phys., 9, 4699-4716, doi:10.5194/acp-9-4699-2009, 2009.

Iida, K., Stolzenburg, M., McMurry, P., Dunn, M. J., Smith, J. N., Eisele, F., and Keady, P.: Contribution of ion-induced nucleation to new particle formation: Methodology and its application to atmospheric observations in Boulder, Colorado, J. Geophys. Res.Atmos., 111, D23201, doi:10.1029/2006JD007167, 2006.

Iida, K., Stolzenburg, M. R., McMurry, P. H., and Smith, J. $\mathrm{N}$.: Estimating nanoparticle growth rates from size-dependent charged fractions: Analysis of new particle formation events in Mexico City, J. Geophys. Res.-Atmos., 113, D05207, doi:10.1029/2007JD009260, 2008.

INSEE: National Institute of Statistics and Economic Studies, Populations légales 2011 de la commune: available at: http://www.insee.fr/fr/themes/tableau_local.asp? ref_id=POP\&millesime $=2010 \&$ typgeo $=$ DEP $\&$ codgeo $=75$, $\mathrm{http} / / / \mathrm{www}$. insee.fr/fr/themes/tableau_local.asp?ref_id= POP \&millesime $=2010 \&$ typgeo $=$ AU2010\& codgeo $=001$, access: 4 June 2010.

Jayaratne, E. R., J-Fatokun, F. O., and Morawska, L.: Air ion concentrations under overhead high-voltage transmission lines, Atmos. Environ., 42, 1846-1856, 2008.

Jayaratne, E. R., Ling, X., and Morawska, L.: Ions in motor vehicle exhaust and their dispersion near busy roads, Atmos. Environ., 44, 3644-3650, doi:10.1016/j.atmosenv.2010.06.043, 2010.

Jayaratne, E. R., Ling, X., and Morawska, L.: Observation of ions and particles near busy roads using a neutral cluster and air ion spectrometer (NAIS), Atmos. Environ., 84, 198-203, doi:10.1016/j.atmosenv.2013.11.045, 2014.

Kanawade, V. P., Tripathi, S. N., Siingh, D., Gautam, A. S., Srivastava, A. K., Kamra, A. K., Soni, V. K., and Sethi, V.: Observations of new particle formation at two distinct Indian subcontinental urban locations, Atmos. Environ., 96, 370-379, doi:10.1016/j.atmosenv.2014.08.001, 2014.

Kerminen, V.-M., Paramonov, M., Anttila, T., Riipinen, I., Fountoukis, C., Korhonen, H., Asmi, E., Laakso, L., Lihavainen, H., Swietlicki, E., Svenningsson, B., Asmi, A., Pandis, S. N., Kulmala, M., and Petäjä, T.: Cloud condensation nuclei production associated with atmospheric nucleation: a synthesis based on existing literature and new results, Atmos. Chem. Phys., 12, 1203712059, doi:10.5194/acp-12-12037-2012, 2012.

Kirkby, J., Curtius, J., Almeida, J., Dunne, E., Duplissy, J., Ehrhart, S., Franchin, A., Gagne, S., Ickes, L., Kurten, A., Kupc, A., Metzger, A., Riccobono, F., Rondo, L., Schobesberger, S., Tsagkogeorgas, G., Wimmer, D., Amorim, A., Bianchi, F., Breitenlechner, M., David, A., Dommen, J., Downard, A., Ehn, M., Flagan, R. C., Haider, S., Hansel, A., Hauser, D., Jud, W., Junninen, H., Kreissl, F., Kvashin, A., Laaksonen, A., Lehtipalo, K., Lima, J., Lovejoy, E. R., Makhmutov, V., Mathot, S., Mikkila, J., Minginette, P., Mogo, S., Nieminen, T., Onnela, A., Pereira, P., Petaja, T., Schnitzhofer, R., Seinfeld, J. H., Sipila, M., Stozhkov, Y., Stratmann, F., Tome, A., Vanhanen, J., Viisanen, Y., Vrtala, A., Wagner, P. E., Walther, H., Weingartner, E., Wex, H., Winkler, P. M., Carslaw, K. S., Worsnop, D. R., Baltensperger, U., and Kulmala, M.: Role of sulphuric acid, ammonia and galactic cosmic rays in atmospheric aerosol nucleation, Nature, 476, 429-433, http://www.nature.com/nature/journal/v476/ n7361/abs/nature10343.html\#supplementary-information, 2011.

Kolarž, P., Gaisberger, M., Madl, P., Hofmann, W., Ritter, M., and Hartl, A.: Characterization of ions at Alpine waterfalls, Atmos. Chem. Phys., 12, 3687-3697, doi:10.5194/acp-12-3687-2012, 2012.

Kulmala, M., Dal maso, M. D., Mäkelä, J. M., Pirjola, L., Väkevä, M., Aalto, P., Miikkulainen, P., Hämeri, K., \#039, and Dowd, C. D.: On the formation, growth and composition of nucleation mode particles, Tellus B, 53, 479-490, doi:10.1034/j.16000889.2001.d01-33.x, 2001.

Kulmala, M., Kerminen, V.-M., Anttila, T., Laaksonen, A., and O'Dowd, C. D.: Organic aerosol formation via sulphate cluster activation, J. Geophys. Res.-Atmos., 109, D04205, doi:10.1029/2003jd003961, 2004a.

Kulmala, M., Laakso, L., Lehtinen, K. E. J., Riipinen, I., Dal Maso, M., Anttila, T., Kerminen, V.-M., Hõrrak, U., Vana, M., and Tammet, H.: Initial steps of aerosol growth, Atmos. Chem. Phys., 4, 2553-2560, doi:10.5194/acp-4-2553-2004, 2004b.

Kulmala, M., Petäjä, T., Nieminen, T., Sipilä, M., Manninen, H. E., Lehtipalo, K., Dal Maso, M., Aalto, P. P., Junninen, H., Paasonen, P., Riipinen, I., Lehtinen, K. E. J., Laaksonen, A., and Kerminen, V.-M.: Measurement of the nucleation of atmospheric aerosol particles, Nat. Protocols, 7, 1651-1667, http://www.nature.com/nprot/journal/v7/n9/abs/ nprot.2012.091.html\#supplementary-information, 2012.

Kulmala, M., Petäjä, T., Ehn, M., Thornton, J., Sipilä, M., Worsnop, D. R., and Kerminen, V.-M.: Chemistry of Atmospheric Nucleation: On the Recent Advances on Precursor Characterization and Atmospheric Cluster Composition in Connection with At- 
mospheric New Particle Formation, Ann. Rev. Phys. Chem., 65, 21-37, doi:10.1146/annurev-physchem-040412-110014, 2014.

Lee, E. S., Xu, B., and Zhu, Y.: Measurements of ultrafine particles carrying different number of charges in on- and near-freeway environments, Atmos. Environ., 60, 564-572, doi:10.1016/j.atmosenv.2012.06.085, 2012.

Leng, C., Zhang, Q., Tao, J., Zhang, H., Zhang, D., Xu, C., Li, X., Kong, L., Cheng, T., Zhang, R., Yang, X., Chen, J., Qiao, L., Lou, S., Wang, H., and Chen, C.: Impacts of new particle formation on aerosol cloud condensation nuclei $(\mathrm{CCN})$ activity in Shanghai: case study, Atmos. Chem. Phys., 14, 11353-11365, doi:10.5194/acp-14-11353-2014, 2014.

Ling, X., Jayaratne, R., and Morawska, L.: The relationship between airborne small ions and particles in urban environments, Atmos. Environ., 79, 1-6, doi:10.1016/j.atmosenv.2013.06.006, 2013.

Ling, X. A., Jayaratne, R., and Morawska, L.: Air ion concentrations in various urban outdoor environments, Atmos. Environ., 44, 2186-2193, doi:10.1016/j.atmosenv.2010.03.026, 2010.

Lopez, M., Schmidt, M., Yver, C., Messager, C., Worthy, D., Kazan, V., Ramonet, M., Bousquet, P., and Ciais, P.: Seasonal variation of $\mathrm{N}_{2} \mathrm{O}$ emissions in France inferred from atmospheric $\mathrm{N}_{2} \mathrm{O}$ and ${ }^{222} \mathrm{Rn}$ measurements, J. Geophys. Res.-Atmos., 117, D14103, doi:10.1029/2012jd017703, 2012.

Lähde, T., Rönkkö, T., Virtanen, A., Schuck, T. J., Pirjola, L., Hämeri, K., Kulmala, M., Arnold, F., Rothe, D., and Keskinen, J.: Heavy Duty Diesel Engine Exhaust Aerosol Particle and Ion Measurements, Environ. Sci. Technol., 43, 163-168, 2009.

Makkonen, R., Asmi, A., Kerminen, V.-M., Boy, M., Arneth, A., Hari, P., and Kulmala, M.: Air pollution control and decreasing new particle formation lead to strong climate warming, Atmos. Chem. Phys., 12, 1515-1524, doi:10.5194/acp-12-15152012, 2012.

Manninen, H. E., Petäjä, T., Asmi, E., Riipinen, N., Nieminen, T., Mikkilä, J., Hõrrak, U., Mirme, A., Mirme, S., Laakso, L., Kerminen, V. M., and Kulmala, M.: Long-term field measurements of charged and neutral clusters using Neutral cluster and Air Ion Spectrometer (NAIS), Boreal Environ. Res., 14, 591-605, 2009.

Manninen, H. E., Nieminen, T., Asmi, E., Gagné, S., Häkkinen, S., Lehtipalo, K., Aalto, P., Vana, M., Mirme, A., Mirme, S., Hõrrak, U., Plass-Dülmer, C., Stange, G., Kiss, G., Hoffer, A., Töro, N., Moerman, M., Henzing, B., de Leeuw, G., Brinkenberg, M., Kouvarakis, G. N., Bougiatioti, A., Mihalopoulos, N., O’Dowd, C., Ceburnis, D., Arneth, A., Svenningsson, B., Swietlicki, E., Tarozzi, L., Decesari, S., Facchini, M. C., Birmili, W., Sonntag, A., Wiedensohler, A., Boulon, J., Sellegri, K., Laj, P., Gysel, M., Bukowiecki, N., Weingartner, E., Wehrle, G., Laaksonen, A., Hamed, A., Joutsensaari, J., Petäjä, T., Kerminen, V.-M., and Kulmala, M.: EUCAARI ion spectrometer measurements at 12 European sites - analysis of new particle formation events, Atmos. Chem. Phys., 10, 7907-7927, doi:10.5194/acp-10-79072010, 2010.

Merikanto, J., Spracklen, D. V., Mann, G. W., Pickering, S. J., and Carslaw, K. S.: Impact of nucleation on global CCN, Atmos. Chem. Phys., 9, 8601-8616, doi:10.5194/acp-9-8601-2009, 2009.

Mirme, A., Tamm, E., Mordas, G., Vana, M., Uin, J., Mirme, S., Bernotas, T., Laakso, L., Hirsikko, A., and Kulmala, M.: A wide- range multi-channel air ion spectrometer, Boreal Environ. Res., 12, 247-264, 2007.

Mäkelä, J. M., Riihelä, M., Ukkonen, A., Jokinen, V., and Keskinen, J.: Comparison of mobility equivalent diameter with KelvinThomson diameter using ion mobility data, J. Chem. Phys., 105, 1562-1571, doi:10.1063/1.472017, 1996.

Nagato, K. and Nakauchi, M.: Experimental study of particle formation by ion-ion recombination, J. Chem. Phys., 141, 164309, doi:10.1063/1.4898376, 2014.

Nilsson, E. D., Paatero, J., and Boy, M.: Effects of air masses and synoptic weather on aerosol formation in the continental boundary layer, Tellus B, 53, doi:10.1034/j.1600-0889.2001.530410.x, 2001.

Oberdörster, G., Oberdörster, E., and Oberdörster, J.: Nanotoxicology: An emerging discipline evolving from studies of ultrafine particles, Environ. Health Persp., 113, 823-839, doi:10.1289/Ehp.7339, 2005.

Pikridas, M., Sciare, J., Freutel, F., Crumeyrolle, S., von der Weiden-Reinmüller, S.-L., Borbon, A., Schwarzenboeck, A., Merkel, M., Crippa, M., Kostenidou, E., Psichoudaki, M., Hildebrandt, L., Engelhart, G. J., Petäjä, T., Prévôt, A. S. H., Drewnick, F., Baltensperger, U., Wiedensohler, A., Kulmala, M., Beekmann, M., and Pandis, S. N.: In situ formation and spatial variability of particle number concentration in a European megacity, Atmos. Chem. Phys., 15, 10219-10237, doi:10.5194/acp-15-10219-2015, 2015.

Puustinen, A., Hämeri, K., Pekkanen, J., Kulmala, M., de Hartog, J., Meliefste, K., ten Brink, H., Kos, G., Katsouyanni, K., Karakatsani, A., Kotronarou, A., Kavouras, I., Meddings, C., Thomas, S., Harrison, R. M., Ayres, J. G., van der Zee, S., and Hoek, G.: Spatial variation of particle number and mass over four European cities, Atmos. Environ., 41, 6622-6636, doi:10.1016/j.atmosenv.2007.04.020, 2007.

Retalis, A., Nastos, P., and Retalis, D.: Study of small ions concentration in the air above Athens, Greece, Atmos. Res., 91, 219228, doi:10.1016/j.atmosres.2008.05.011, 2009.

Riccobono, F., Schobesberger, S., Scott, C. E., Dommen, J., Ortega, I. K., Rondo, L., Almeida, J., Amorim, A., Bianchi, F., Breitenlechner, M., David, A., Downard, A., Dunne, E. M., Duplissy, J., Ehrhart, S., Flagan, R. C., Franchin, A., Hansel, A., Junninen, H., Kajos, M., Keskinen, H., Kupc, A., Kürten, A., Kvashin, A. N., Laaksonen, A., Lehtipalo, K., Makhmutov, V., Mathot, S., Nieminen, T., Onnela, A., Petäjä, T., Praplan, A. P., Santos, F. D., Schallhart, S., Seinfeld, J. H., Sipilä, M., Spracklen, D. V., Stozhkov, Y., Stratmann, F., Tomé, A., Tsagkogeorgas, G., Vaattovaara, P., Viisanen, Y., Vrtala, A., Wagner, P. E., Weingartner, E., Wex, H., Wimmer, D., Carslaw, K. S., Curtius, J., Donahue, N. M., Kirkby, J., Kulmala, M., Worsnop, D. R., and Baltensperger, U.: Oxidation Products of Biogenic Emissions Contribute to Nucleation of Atmospheric Particles, Science, 344, 717-721, doi:10.1126/science.1243527, 2014.

Rose, C., Boulon, J., Hervo, M., Holmgren, H., Asmi, E., Ramonet, M., Laj, P., and Sellegri, K.: Long-term observations of cluster ion concentration, sources and sinks in clear sky conditions at the high-altitude site of the Puy de Dôme, France, Atmos. Chem. Phys., 13, 11573-11594, doi:10.5194/acp-1311573-2013, 2013. 
Salma, I., Borsós, T., Weidinger, T., Aalto, P., Hussein, T., Dal Maso, M., and Kulmala, M.: Production, growth and properties of ultrafine atmospheric aerosol particles in an urban environment, Atmos. Chem. Phys., 11, 1339-1353, doi:10.5194/acp-111339-2011, 2011.

Sciare, J., d'Argouges, O., Zhang, Q. J., Sarda-Estève, R., Gaimoz, C., Gros, V., Beekmann, M., and Sanchez, O.: Comparison between simulated and observed chemical composition of fine aerosols in Paris (France) during springtime: contribution of regional versus continental emissions, Atmos. Chem. Phys., 10, 11987-12004, doi:10.5194/acp-10-11987-2010, 2010.

Siingh, D., Gautam, A. S., Kamra, A. K., and Komsaare, K.: Nucleation events for the formation of charged aerosol particles at a tropical station - Preliminary results, Atmos. Res., 132-133, 239-252, doi:10.1016/j.atmosres.2013.05.024, 2013.

Stanier, C. O., Khlystov, A. Y., and Pandis, S. N.: Nucleation Events During the Pittsburgh Air Quality Study: Description and Relation to Key Meteorological, Gas Phase, and Aerosol Parameters Special Issue of Aerosol Science and Technology on Findings from the Fine Particulate Matter Supersites Program, Aerosol Sci. Technol., 38, 253-264, doi:10.1080/02786820390229570, 2004.

Svensmark, H., Pedersen, J. O. P., Marsh, N. D., Enghoff, M. B., and Uggerhoj, U. I.: Experimental evidence for the role of ions in particle nucleation under atmospheric conditions, Proceed. Roy. Soc. A, 463, 385-396, doi:10.1098/rspa.2006.1773, 2007.

Tammet, H., Hõrrak, U., and Kulmala, M.: Negatively charged nanoparticles produced by splashing of water, Atmos. Chem. Phys., 9, 357-367, doi:10.5194/acp-9-357-2009, 2009.

Tammet, H., Komsaare, K., and Hõrrak, U.: Intermediate ions in the atmosphere, Atmos. Res., 135-136, 263-273, doi:10.1016/j.atmosres.2012.09.009, 2014.

Tiitta, P., Miettinen, P., Vaattovaara, P., Laaksonen, A., Joutsensaari, J., Hirsikko, A., Aalto, P., and Kulmala, M.: Road-side measurements of aerosol and ion number size distributions: A comparison with remote site measurements, Boreal Environ. Res., 12, 311-321, 2007.

Tuch, T. M., Haudek, A., Müller, T., Nowak, A., Wex, H., and Wiedensohler, A.: Design and performance of an automatic regenerating adsorption aerosol dryer for continuous operation at monitoring sites, Atmos. Meas. Tech., 2, 417-422, doi:10.5194/amt-2-417-2009, 2009.

Wang, Z. B., Hu, M., Wu, Z. J., Yue, D. L., He, L. Y., Huang, X. F., Liu, X. G., and Wiedensohler, A.: Long-term measurements of particle number size distributions and the relationships with air mass history and source apportionment in the summer of Beijing, Atmos. Chem. Phys., 13, 10159-10170, doi:10.5194/acp13-10159-2013, 2013.

Wehner, B., Siebert, H., Ansmann, A., Ditas, F., Seifert, P., Stratmann, F., Wiedensohler, A., Apituley, A., Shaw, R. A., Manninen, H. E., and Kulmala, M.: Observations of turbulence-induced new particle formation in the residual layer, Atmos. Chem. Phys., 10, 4319-4330, doi:10.5194/acp-10-4319-2010, 2010.

Wiedensohler, A., Cheng, Y. F., Nowak, A., Wehner, B., Achtert, P., Berghof, M., Birmili, W., Wu, Z. J., Hu, M., Zhu, T., Takegawa, N., Kita, K., Kondo, Y., Lou, S. R., Hofzumahaus, A., Holland, F., Wahner, A., Gunthe, S. S., Rose, D., Su, H., and Pöschl, U.: Rapid aerosol particle growth and increase of cloud condensation nucleus activity by secondary aerosol formation and condensation: A case study for regional air pollution in northeastern China, J. Geophys. Res.-Atmos., 114, D00G08, doi:10.1029/2008jd010884, 2009.

Wiedensohler, A., Birmili, W., Nowak, A., Sonntag, A., Weinhold, K., Merkel, M., Wehner, B., Tuch, T., Pfeifer, S., Fiebig, M., Fjäraa, A. M., Asmi, E., Sellegri, K., Depuy, R., Venzac, H., Villani, P., Laj, P., Aalto, P., Ogren, J. A., Swietlicki, E., Williams, P., Roldin, P., Quincey, P., Hüglin, C., Fierz-Schmidhauser, R., Gysel, M., Weingartner, E., Riccobono, F., Santos, S., Grüning, C., Faloon, K., Beddows, D., Harrison, R., Monahan, C., Jennings, S. G., O’Dowd, C. D., Marinoni, A., Horn, H.-G., Keck, L., Jiang, J., Scheckman, J., McMurry, P. H., Deng, Z., Zhao, C. S., Moerman, M., Henzing, B., de Leeuw, G., Löschau, G., and Bastian, S.: Mobility particle size spectrometers: harmonization of technical standards and data structure to facilitate high quality long-term observations of atmospheric particle number size distributions, Atmos. Meas. Tech., 5, 657-685, doi:10.5194/amt5-657-2012, 2012.

Virkkula, A., Hirsikko, A., Vana, M., Aalto, P. P., Hillamo, R., and Kulmala, M.: Charged particle size distributions and analysis of particle formation events at the Finnish Antarctic research station Aboa, Boreal Env. Res., 12, 397-408, 2007.

World Health Organization (WHO): WHO Handbook on Indoor Radon: A Public Health Perspective, Geneva, 2009.

Wu, Z., Hu, M., Liu, S., Wehner, B., Bauer, S., Ma Bling, A., Wiedensohler, A., Petäjä, T., Dal Maso, M., and Kulmala, M.: New particle formation in Beijing, China: Statistical analysis of a 1-year data set, J. Geophys. Res.-Atmos., 112, D09209, doi:10.1029/2006JD007406, 2007.

Wu, Z., Hu, M., Lin, P., Liu, S., Wehner, B., and Wiedensohler, A.: Particle number size distribution in the urban atmosphere of Beijing, China, Atmos. Environ., 42, 7967-7980, doi:10.1016/j.atmosenv.2008.06.022, 2008.

Yli-Juuti, T., Nieminen, T., Hirsikko, A., Aalto, P. P., Asmi, E., Hõrrak, U., Manninen, H. E., Patokoski, J., Dal Maso, M., Petäjä, T., Rinne, J., Kulmala, M., and Riipinen, I.: Growth rates of nucleation mode particles in Hyytiälä during 20032009: variation with particle size, season, data analysis method and ambient conditions, Atmos. Chem. Phys., 11, 12865-12886, doi:10.5194/acp-11-12865-2011, 2011.

Yu, F.: Ion-mediated nucleation in the atmosphere: Key controlling parameters, implications, and look-up table, J. Geophys. Res.Atmos., 115, D03206, doi:10.1029/2009JD012630, 2010.

Yu, F. and Turco, R. P.: The role of ions in the formation and evolution of particles in aircraft plumes, Geophys. Res. Lett., 24, 1927-1930, 1997.

Yu, F. and Turco, R. P.: Ultrafine aerosol formation via ion-mediated nucleation, Geophys. Res. Lett., 27, 883-886, doi:10.1029/1999GL011151, 2000.

Yu, F. and Turco, R. P.: The size-dependent charge fraction of sub-3$\mathrm{nm}$ particles as a key diagnostic of competitive nucleation mechanisms under atmospheric conditions, Atmos. Chem. Phys., 11, 9451-9463, doi:10.5194/acp-11-9451-2011, 2011.

Yu, H., Zhou, L. Y., Dai, L., Shen, W. C., Zheng, J., Ma, Y., and Chen, M. D.: Nucleation and growth of sub-3 nm particles in the polluted urban atmosphere of a megacity in China, Atmos. Chem. Phys. Discuss., 15, 18653-18690, doi:10.5194/acpd-1518653-2015, 2015. 
Zhang, Q., Stanier, C. O., Canagaratna, M. R., Jayne, J. T., Worsnop, D. R., Pandis, S. N., and Jimenez, J. L.: Insights into the chemistry of new particle formation and growth events in Pittsburgh based on aerosol mass spectrometry, Environ. Sci. Technol., 38, 4797-4809, doi:10.1021/es035417u, 2004.
Xiao, S., Wang, M. Y., Yao, L., Kulmala, M., Zhou, B., Yang, X., Chen, J. M., Wang, D. F., Fu, Q. Y., Worsnop, D. R., and Wang, L.: Strong atmospheric new particle formation in winter in urban Shanghai, China, Atmos. Chem. Phys., 15, 1769-1781, doi:10.5194/acp-15-1769-2015, 2015. 